\title{
Kairos in Innovation Policy
}

\section{Theoretical Background and Practical Implications for the Triple Helix}

\author{
Michael Rothgang | ORCID: 0000-0001-8328-0295 \\ RWI-Leibniz-Institute for Economic Research, Essen, \\ Nordrhein-Westfalen, Germany \\ rothgang@rwi-essen.de \\ Bernhard Lageman \\ RWI-Leibniz-Institute for Economic Research, Essen, \\ Nordrhein-Westfalen, Germany
}

\begin{abstract}
A kairos constellation designates a temporarily existing opportunity for a group of actors to take advantage of a coincidence of favourable circumstances in order to realise a shared target. Starting from the observation that kairos constellations are ubiquitous in human individual and social life, the research question of this paper is how the Triple Helix and the wider innovation policy research literature deals with such constellations. The authors develop a conceptual framework for kairos constellations and discuss empirical evidence that kairos constellations have been scrutinized in innovation research literature. Then, the concept is applied to an example from the Triple Helix - based cluster policy. The key message of this paper is that Triple Helix researchers should systematically study kairos constellations because they are a critical force in the evolution of innovations systems as well as business firms, which has not yet been systematically examined.
\end{abstract}

\section{Keywords}

Cluster policy - Innovation policy - Path dependence - Triple helix - Window of opportunity 


\section{Arabic}

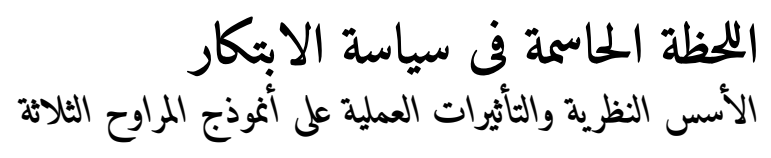

Michael Rothgang, Bernhard Lageman

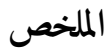

تشكل تكونات كايروس فزصة متاحة مؤقتا لمجموعة من الجهات الفاعلة للاستفادة من

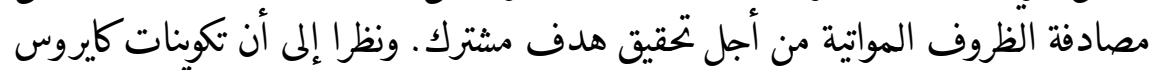

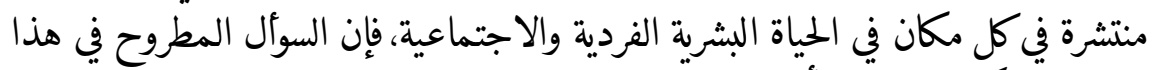

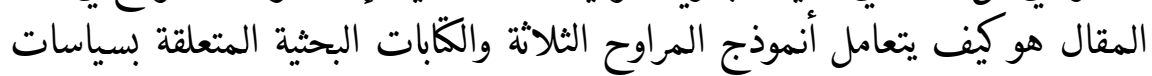

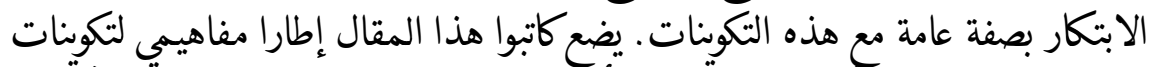

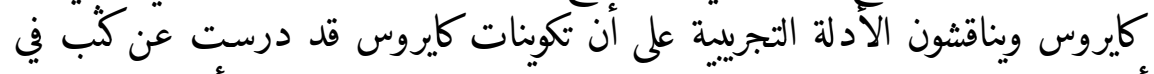

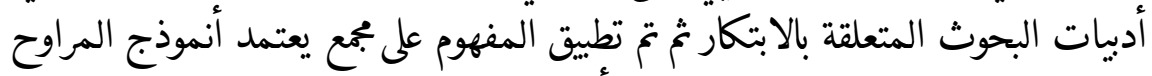

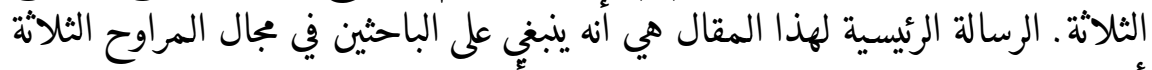

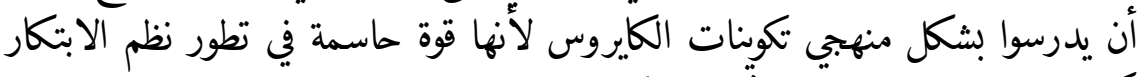

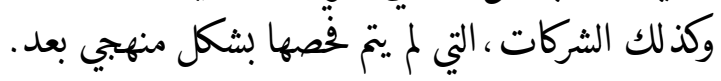

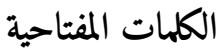

شباك الفرص ؛ المراوح الثلاثة؛ سياسة الابتكار ؛ سياسة المجموعات ؛تلازم المسارات 


\title{
Chinese
}

\section{创新政策中的凯罗斯：理论背景和对三螺旋的实 践启示}

\author{
Michael Rothgang, Bernhard Lageman
}

\section{摘要}

凯罗斯(kairos) 集合是指一群活动者通过利用有利的条件和机缘巧合来实现共同目 标的机会窗 $\square$ 。本文基于对凯罗斯集合作为人类个体和社会生活中普遍存在现象的 观察, 提出研究问题如下: 凯罗斯集合如何体现在三螺旋和更广泛的创新政策研究 文献中? 作者构建了凯罗斯集合的概念框架, 并讨论创新研究文献中涉及到凯罗斯 集合的研究。然后, 这个概念被应用到一个基于 “三重螺旋” 模型的（创新）群 集政策案例分析。虽然凯罗斯集合是创新系统和商业公司发展的矢键力量, 但是对 这一现象的研究却不足, 因此本文建议三螺旋研究者应该对此进行系统的研究。

\section{关键字}

机会窗 $\square$, 三重螺旋, 创新政策, 集群政策, 路径依赖

\section{French}

\section{Kairos dans la politique d'innovation}

Contexte théorique et implications pratiques pour la Triple Hélice

\author{
Michael Rothgang, Bernhard Lageman
}

\section{Résumé}

Une constellation de kairos désigne une opportunité temporairement existante pour un groupe d'acteurs de profiter d'une coïncidence de circonstances favorables afin de réaliser un objectif partagé. Partant de l'observation que les constellations de kairos sont omniprésentes dans la vie individuelle et sociale humaine, la question 
de recherche de cet article est de savoir comment la Triple Hélice et la littérature de recherche sur les politiques d'innovation au sens large traitent ces constellations. Les auteurs développent un cadre conceptuel pour les constellations de kairos et discutent des preuves empiriques que les constellations de kairos ont été examinées dans la littérature de recherche sur l'innovation. Ensuite, le concept est appliqué à un exemple de la politique de cluster basée sur la Triple Hélice. Le message clé de cet article est que les chercheurs de la Triple Hélice devraient systématiquement étudier les constellations de kairos car elles sont une force critique dans l'évolution des systèmes d'innovation ainsi que des entreprises, ce qui n’a pas encore été systématiquement examiné.

\title{
Mots clés
}

Fenêtre d'opportunité; Triple Hélice; Politique d'innovation ; Politique de cluster ; Path dependence

\section{Portuguese}

\section{Kairos na política de inovação}

Antecedentes Teóricos e Implicações Práticas para a Hélice Tripla

\author{
Michael Rothgang, Bernhard Lageman
}

\section{Resumo}

Uma constelação de kairós designa uma oportunidade temporariamente existente para um grupo de atores tirar vantagem de uma coincidência de circunstâncias favoráveis a fim de realizar um objetivo comum. Partindo da observação de que as constelações de kairós são onipresentes na vida individual e social humana, a questão de pesquisa deste artigo é como a Hélice Tripla e a literatura de pesquisa de política de inovação mais ampla lidam com tais constelações. Os autores desenvolvem uma estrutura conceitual para as constelações de kairós e discutem evidências empíricas de que as constelações de kairós foram escrutinadas na literatura de pesquisa em inovação. Em seguida, o conceito é aplicado a um exemplo da política de cluster baseada em Triple Helix. A mensagem principal deste artigo é que os pesquisadores da Triple Helix devem estudar sistematicamente as constelações de kairós porque elas são uma força crítica na evolução dos sistemas de inovação e das empresas, o que ainda não foi sistematicamente examinado. 


\title{
Palavras-chave
}

Janela de oportunidade; Hélice Tripla; Política de inovação, política de cluster, path dependence

\section{Russian}

\section{Кайрос в инновационной стратегии. Теоретическая база и практическое применение в концепции Тройной спирали}

\author{
М. Ротганг, Б. Лагеман
}

\begin{abstract}
Аннотация
Явление «счастливого момента К Кайрос обозначает временно существующую возможность для группы участников, в условиях благоприятного стечения обстоятельств получающих определенные преимущества в достижении поставленной цели. Явление Кайрос повсеместно встречается в жизни людей, поэтому задачей настоящего исследования является поиск таких примеров в концепции Тройной спирали и более масштабных исследованиях, посвященных инновационным стратегиям. Авторами разработана концептуальная модель явления Кайрос и определены эмпирические доказательства его появления, подтверждающие возможность его исследования в работах, посвященных инновациям. Далее, модель апробирована на примере Кластерной политики в рамках концепции Тройной спирали. Ключевым выводом настоящей работы является то, что исследователи Тройной спирали должны систематически следить за наличием условий, способствующих формированию Кайрос, поскольку они оказывают критическое влияние на развитие как инновационных систем, так и коммерческих фирм, которые до настоящего времени не изучались систематически.
\end{abstract}

\section{Ключевые слова}

Окно возможностей; Тройная спираль; Инновационная политика, Кластерная политика, Эффект колеи 


\section{Spanish}

\section{Kairos en la política de innovación}

Antecedentes teóricos e implicaciones prácticas de la Triple Hélice

Michael Rothgang, Bernhard Lageman

\section{Resumen}

Una constelación de kairos designa una oportunidad que existe temporalmente para que un grupo de actores aproveche una coincidencia de circunstancias favorables para lograr un objetivo compartido. Partiendo de la observación de que las constelaciones de kairos son omnipresentes en la vida humana individual y social, la pregunta de investigación de este artículo es cómo la Triple Hélice y la literatura de investigación de políticas de innovación más amplia se ocupa de tales constelaciones. Los autores desarrollan un marco conceptual para las constelaciones de kairos y discuten la evidencia empírica de que las constelaciones de kairos han sido escrutadas en la literatura de investigación sobre innovación. Luego, el concepto se aplica a un ejemplo de la política de clúster basada en Triple Hélice. El mensaje clave de este artículo es que los investigadores de Triple Helix deberían estudiar sistemáticamente las constelaciones de kairos porque son una fuerza crítica en la evolución de los sistemas de innovación, así como de las empresas comerciales, que aún no se ha examinado sistemáticamente.

\section{Palabras clave}

Ventana de oportunidad; Triple hélice; Política de innovación, política de clústeres, path dependence

\section{Introduction}

Research using the Triple Helix as its guiding principle has uncovered a wide body of evidence on the emergence, structures and functioning of networks that developed between universities, industry and government (Cai and Etzkowitz 202O; Etzkowitz and Leydesdorff 2000; Etzkowitz and Zhou 2018; Ranga and Etzkowitz 2013). The studies conducted under the umbrella of this integrative research approach focus on the sources and mechanisms of 
knowledge production that have been in place since the emergence of sciencebased industries, and that will increasingly shape human life in the 21st century. The analyses reveal the deepening interconnections between these three spheres of innovation at the micro, meso and macro levels, and stress the increasing importance of universities in knowledge production. The Triple Helix model unveils the dynamics of these constellations and thus offers an evolutionary theory of innovation processes (Lawton Smith and Leydesdorff 2014; Leydesdorff 2000).

It is no coincidence that the eponymous metaphor of this research initiative comes from evolutionary biology, specifically molecular genetics. It is, after all, suitable for addressing essential features of social development processes. At the same time, it seems straightforward to extend the concept at one critical point. Unlike the evolution of organisms from flora and fauna the evolution of human organisations, institutions and societies is strongly influenced by the directly formative intervention of human consciousness. It is human actors, whether acting individually or collectively, that shape the development of Triple Helix networks. The principal role of Triple Helix actors in the processes that lead to the creation of Triple Helix networks is broadly addressed in the relevant research literature (e.g., Etzkowitz, Zhou 2018; Ranga and Etzkowitz 2013).

Concurrently, there are still open questions concerning the human and environmental factors that lead to relevant decisions and actions. Empirical studies on the Triple Helix in individual countries, regions and/or industries devote considerable space to the role of individual actors (e.g., Etzkowitz 2012, on the origins of innovation policy in the New England states; Etzkowitz and Zhou 2018: 239-255, on a case study of Silicon Valley). The question of why, how and under what conditions individual actors or groups of actors trigger a specific direction in the development of network structures remains largely open, leaving a research gap in Triple Helix research literature. Our article ${ }^{1}$ addresses this specific and strategically important aspect of innovation policy decision-making: The situations in which responsible actors make landmark decisions that influence the long-term development of Triple Helix structures, and in so doing establish path dependencies. We make use of a metaphorkairos - that is suitable for placing what is referred to in a broader context of scientific and political discourses.

The term originally designated a figure from ancient Greek mythology: the god kairos, youngest son of Zeus, who provides the actor with an extremely favourable, but transitional opportunity to set an extraordinary project in motion (Demandt 2015: 1n, 2d). The awareness and use of the right moment are decisive for the success of the activity or project envisaged. A second meaning 
of the term kairos, which was originally minted in archery and weaving for the designation of physical processes, originates in Greek rhetoric (Bartunek and Necochea 2000: 104). In this context, kairos aims at the orator's skilful exploitation of the specific circumstances of the addressed constellation of speech, audience and circumstances. Later the concept was also used in Hebrew and Christian texts, in a sense which is related to the mental construct we have in mind, namely: "focus on a decisive point in time, a critical situation when a right decision must be made" (Kittel 1965 as cited by Bartunek and Necochea 2000: 105). Of course, in this context the kairos concept was theologically charged, kairos constellations being viewed as the result of divine predestination (Kasper 2009: 1129-1131). ${ }^{2}$ In modern usage, kairos designates according to the Merriam-Webster dictionary "a time when conditions are right for the accomplishment of a crucial action: the opportune and decisive moment."3 The concept has recently been used in social sciences. Two noteworthy examples are Allisons study on the looming Great Power conflict between the USA and China and of the historical precedents of a "Thukydides's Trap" investigated by him (Allison 2019), and Clark's study on the "accidental" outbreak of World War I (Clark 2013).

While the kairos concept has found its way in the humanities and even seems to enjoy increasing popularity, economists and innovation researchers have hardly made use of it. Instead, they are more familiar with the approximate English equivalent term "windows of opportunity". However, the potentials of the problem complex addressed by this term have not yet been dealt with exhaustively. A Scopus ${ }^{4}$ search based on the fields title, abstracts and keywords in the disciplines of economics, management and social sciences revealed that the term "kairos" occurred in 243 publications. When the search was extended to all possible search fields, this figure increased to 2,390 occurrences. An accordingly limited search for the term of "window of opportunity" yielded 1,598 entries, and the extended search revealed 6,426 entries.

The use of both terms in scientific contexts shows that they refer to a relevant topic addressed in many disciplines, which has certainly not lost its importance in the present. Thus, the actual Wikipedia article states, apparently alluding to the exceptional significance of digital technologies and artificial intelligence for humanity: "However, the relevancy of kairos is at its peak as the world has rapidly transformed into a society dependent on digital technology."5 In the following, we use the terms kairos and "windows of opportunity" interchangeably, but we give preference to the term kairos. The reason is that this term seems more suitable for directing the observer's view to the existence of a bundle of different aspects of a complex decision-making situation, comprising more elements than its critical temporal structure, which is primarily addressed by "window of opportunity". 
Starting from the observation that kairos constellations are ubiquitous in human individual and social life the research question of this article is how kairos constellations were dealt with in the Triple Helix and the wider innovation policy research literature. In doing so, we take a look at the extent to which various disciplines have addressed kairos constellations and the question in which contexts innovation research has encountered the kairos phenomenon, even without classifying it under this label. We develop a conceptual framework for Kairos constellations and apply it to an example from the Triple Helix - based cluster policy.

Our methodological approach is basically a conceptual desktop study that combines deductive and inductive elements and is based on the analysis of a wide range of research publications. Deduction from existing bodies of theory is supplemented by inductive conclusions from empirical work on the history of innovation policy. In a first step, we look at the role of kairos constellations in the stock of theories of the respective science disciplines. In a second step, we ask how empirical research on the courses of innovation policy deals with the kairos topic. We identify ideas from the literature that provide building blocks for a model of kairos constellations such as path dependency in evolutionary economics (Allen 2016; Doper 2016; Martin 2010; Nelson and Winter 1996), windows of locational opportunity in regional economics (Bathelt and Glückler 2018; Boschma 1996a, 1996b) or kairos constellations in engineering research (Tyre and Orlowski 1994). In a third step, we check the usefulness of the kairos model by applying it to the example of cluster policy. In addition to the research papers available on this subject, we also draw on the results of our own empirical work.

In detail, our research is directed by four questions:

1 What is a kairos constellation in the Triple Helix and which structural contexts, subjective and objective factors characterise a kairos constellation in innovation policy?

2 How is the kairos phenomenon dealt with in different strands of the research literature?

3 Are there examples for kairos constellations in the practiced innovation policy of market economies?

4 Are there kairos constellations in cluster policy that can serve as showcase examples, and, if so, under what conditions do they appear?

The analysis is based on a specific understanding of the Triple Helix model, innovation policy, and cluster policy. The Triple Helix model focuses the observer's attention on the strategic importance of the interactions between universities, industry and government. Extended models such as a quadruple helix model may include other social institutions as an independent fourth pole in the analysis like, for instance, non-governmental organisations (Leydesdorff 
2012). These organisations may contribute decisively to the dynamics of innovation in knowledge-based societies and lead to the emergence of hybrid organisations linking the three key institutional spheres (universities, industry and government) of an innovating economy (Cai et al. 2017; Etzkowitz and Leydesdorff 2000; Etzkowitz and Zhou 2018).

We consider innovation policy to be the efforts of governmental actors aimed at creating the institutional and educational preconditions for a knowledgebased society. These efforts might try to increase innovative strength by promoting research, innovation and technological competitiveness that also encourage sustainable growth, employment and general welfare. We prefer a broad definition that goes well beyond the concept of "technology policy" and includes all attempts by the state to influence those parts of the innovation system that are accessible to public influence (similar in scope Borrás and Edquist 2019: 39; Cai et al. 2017: 240). Given these considerations, innovation policy itself is not only a part of the Triple Helix, but is also specifically designed to enhance the Triple Helix.

Cluster policy comprises all activities of national, regional and local governmental actors that aim to enhance the emergence of new, or the development of existing clusters of firms, research organisations and connected organisations and institutions. Because of the increasingly widespread promotion of technology clusters, cluster policy has become a key component of a regionally oriented innovation policy. In these contexts, cluster policy aims at the development of spatially bound Triple Helices by assigning a central role to universities and research organisations.

The structure of our paper is as follows. In section 2, a model of kairos constellations is developed (research question 1). Section 3 first contextualises the model in relation to different strands of academic research (research question 2), and discusses the empirical evidence for kairos constellations found in innovation research literature (research question 3). Section 4 discusses the role of kairos constellations in cluster policy in Germany (research question 4). Section 5 summarizes and discusses the results.

\section{1}

\section{What is a kairos Constellation?}

The Triple Helix model focuses the attention of researchers on the dynamics of relationships between universities, industry and government in the process of knowledge generation and utilisation in knowledge-based societies (Cai and Etzkowitz 202O; Etzkowitz and Zhou 2018). Important directional decisions in 
innovation policy, such as the decision to promote a promising new technology through joint efforts by industry, government and academic institutions, or to strengthen property rights in technological innovations, can establish trajectories that determine an institutional or sectoral development path for a long time to come. The primary decision to determine funding targets and instruments forms the starting point of a trajectory. This decision does not guarantee a favourable development of events in the public interest, neither at the starting point of the development path taken nor at later stages.

Decisions that initiate path-establishing or path-changing developments are based on a choice selected from several options, there are always alternative possibilities. Well-intentioned actions can have unintended side effects or end in failure. Our focus is on decisions that establish trajectories in the dynamic of the Triple Helix. Behind these decisions are individuals who determine actions within their sphere of responsibility at critical junctures in the development of pathways (David 2006: 187), the future consequences of which they can only foresee to a limited extent. A kairos constellation in the development of the Triple Helix designates a temporarily limited option space in which a group of responsible actors recognise a pending opportunity to influence the course of development in their area of responsibility in a decisive way. This opportunity arises due to a fortunate coincidence of favourable circumstances. If the actors decide to act, they are guided by the motive to take advantage of the opportunity that they have identified. The prospects of success are uncertain at the time of the decision.

Figure 1 presents our schematic depiction of a kairos constellation. In the left column, a constellation of circumstances opens the temporary possibility

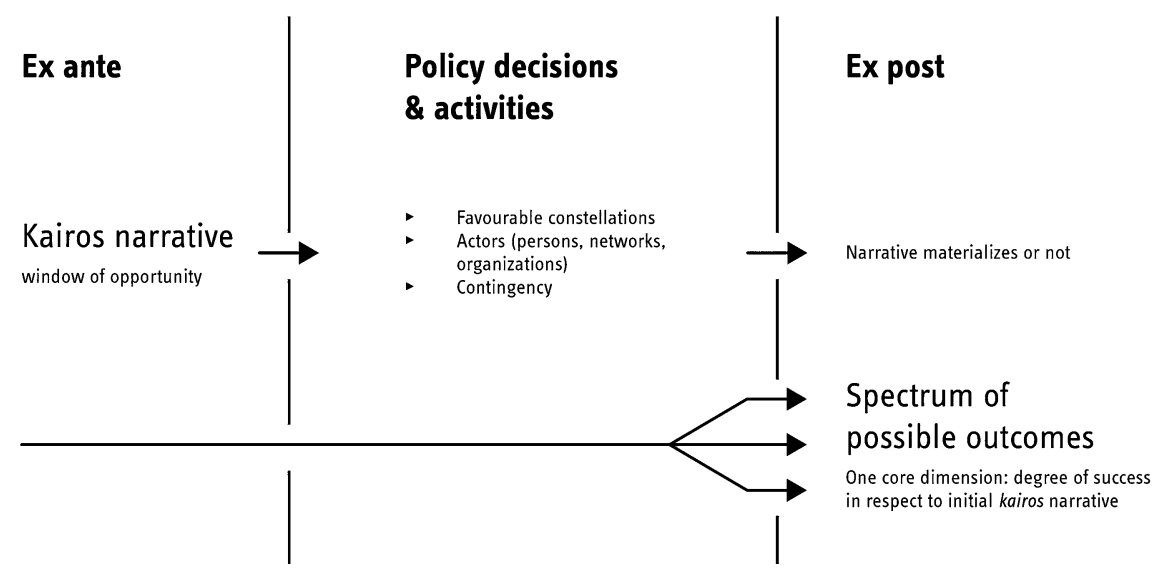

FIGURE 1 Basic structure of a kairos constellation SOURCE: AUTHOR'S OWN DEPICTION 
for action. The opening of this window of opportunity is described by a narrative that reveals its perception by the actors. The middle column summarises the combination of the favourable constellation, the actors' decision to take advantage of the opportunity and the resulting activities. Since the processes that follow from the decision are complex and cannot be easily controlled, contingency is always involved in the implementation of the decision. The righthand column represents the results that are only visible ex-post. The decision in the kairos constellation leads to results that deviate from the desired results to a greater or lesser degree, either positively or negatively.

This diagram of kairos constellations sketched out here is not identical with but related to the concept of "creative response" developed by Schumpeter over 100, respectively 70 years ago (2006 [1912]; 1947). The principle formulated by Schumpeter defines the kernel of entrepreneurial decisions. Analysing new and unusual challenges that fell outside the framework of the familiar, routine procedures of a more or less stationary economy, he addressed entrepreneurial reactions to changes in the economic, social and institutional environment and classified them as "creative response". This was to be distinguished from the "adaptive response" analysed in classical economic theory (see also the critical appraisal in Antonelli 2011, 2015). Schumpeter's analysis captures essential features of the constellations of action that we address in this paper in the form of three essential characteristics of an individual's response:

"First, from the standpoint of the observer who is in full possession of all relevant facts, it can always be understood ex post; but it can practically never be understood ex ante; that is to say, it cannot be predicted by applying the ordinary rules of inference from the pre-existing facts."

"Secondly, creative response shapes the whole course of subsequent events and their 'long run' outcome ... Creative response changes social and economic situations for good, or, to put it differently, it creates situations from which there is no bridge to the situations that might have emerged in its absence."

"Thirdly, creative response - the frequency of its occurrence in a group, its intensity and success or failure - has obviously something, be that more or little, to do (a) with quality of the personnel available in a society, (b) with relative quality of personnel, that is, with quality available to a particular field of activity relative to quality available, at the same time, to others, and (c) with individual decisions, actions, and patterns of behavior." 
Schumpeter considered the initiator and executor of the "creative response" as the innovative entrepreneur (Schumpeter Mark I). He later emphasised the role of large entrepreneurial enterprises and their research departments that had substantial R\&D capacities (Schumpeter Mark II 1975). Mazzucato's recent analysis (Mazzucato 2014) argues that entrepreneurship is also practised by actors working within large governmental units and other non-profit organisations, such as universities, ministries or research institutes. Similarly, entrepreneurship within large companies, for which the term "intrapreneurship" has been coined, is a very important part of the contemporary corporate culture. It is straightforward to conclude that compared to Schumpeter's world the "creative response" in knowledge-based societies and an ever-changing contemporary socio-economic environment is an important issue for Triple Helix actors.

\subsection{Constitutive Elements of kairos Constellations}

From the perspective of an individual actor or group of actors, the major constituents of a kairos constellation in innovation policy are: (i) evolution of the relevant technology field, (ii) the presence of capable firm actors and knowledge producers; (iii) the structural, institutional and regulatory environment; (iv) a high degree of uncertainty with regard to the expected results of the intervention and the attitude of core actors towards risks and (v) the kairos constellation narrative. This narrative expresses the actors' expectations with regard to the economic and technological potential of the existing technology and the resource basis necessary for technology development. We have schematised a basic constellation in Figure 2.

(ii) Triple Helix Actors

- Firm representatives, universities, research institutions

- Individual persons, functioning networks

(i) Technology evolution $\longleftarrow \begin{aligned} & \text { Windows of } \\ & \text { Knowledge accumulation, } \\ & \text { path dependency }\end{aligned}$
opportunity situations $\stackrel{\substack{\text { (iii) Environment } \\ \text { Legal, institutional and } \\ \text { structural factors }}}{\longrightarrow}$

(v) Kairos narrative

- Expectation of future development

- Resources needed to attain policy targets (iv) High degree of uncertainty

- Future technology path

- Market development

FIGURE 2 Characteristic patterns of kairos constellations in innovation policy SOURCE: AUTHOR'S OWN DEPICTION 
Although extended phases of incremental improvements characterise both technology evolution and firms' $R \& D$ investments, technological progress is also characterised by periodic moments of revolutionary change, backlogs, leaps, unexpected recombinations of already existing technologies, and the appearance of alternative disruptive technologies that challenge the established technologies or may even make them obsolete (Arthur 2009). The decision by political actors to devote resources to new technologies is often influenced by other Triple Helix actors, for example academic and economic interest groups. Of course, environmental factors, for instance actual global market developments, or critical environmental challenges are important in such decision processes.

This effort to influence further technological development can only be successful if the necessary resource base for such a joint effort already exists or can be created within a reasonable time. Adequate industrial capacities are a precondition as well as efficient research facilities. The better the existing innovation system is equipped to take on new and unconventional technological paths, the higher the chances of successfully tackling the new tasks.

The reaction to kairos constellations also depends on the external environment, like the regulatory environment and its openness towards the development of a new technology. As Cai et al. (2017) argue, a wide range of enabling conditions that include both tangible and intangible factors, influence the capacity of a regional innovation system to react to technological and economic challenges. On a more aggregate political-geographical level, the same applies to national innovation systems.

Although each kairos constellation shows a temporal structure with a limited time span, in the extreme case the relevant critical time span for the decision may reduce to a brief moment. In other cases it can cover longer periods. Thus, the actor(s) observe a varying temporal structure for a "window of opportunity". On the macro level, kairos moments in innovation policy are pivots in the logic of innovation processes where government interventions play a noticeable role for future development. On the meso and micro levels, the development of these moments often occurs without governmental intervention, and with other actors playing the key role.

\subsection{Actor $(s)$}

A kairos constellation always refers to actors who are capable of making decisions and who have the necessary resource base to seriously influence the course of events. In innovation policy, these are primarily the representatives of the responsible government authorities. In contrast, in kairos constellations that are characterised by the cooperative engagement of firms, academic and 
governmental authorities, we are dealing with a group, more precisely a network of actors.

From the point of view of the external observer, kairos constellations pose a challenge to the decision-maker(s), which is characterised by an apparently available opportunity and an associated risk of failure. This challenge can only be met if decision-makers recognise the emerging opportunity and decide to devote resources to a new goal. At critical junctures of institutional and technological evolution, decisions in follow-up kairos constellations can establish long-acting path dependencies or reinforce already existing path dependencies. Our theoretical framework of kairos constellations addresses both the major constituents of kairos constellations and the underlying temporal structure.

In Triple Helix constellations, decision-making is usually not concentrated in a single group of governmental decision-makers, such as a ministerial department or the head office of a ministry assembled around a key individual. Organisations from all strings of the Triple Helix are engaged in a cooperative project. Thus, the minimum number of participating organisations is three (one from each string). In most cases, a substantially larger number of organisations is involved. Although hierarchical relationships may exist in some of the participating institutions, this hierarchy is unlikely to be representative of the network as a whole. In other words, we are dealing with a network structure within which various key actors work together in a consensual manner. Under these conditions, different interests are balanced in a kairos constellation to achieve a common goal. The respective decision-making processes in innovation networks can take place in very different ways and show both "democratic" and "hierarchical" features depending on the relevant internal power relations.

Uncertainty concerning the future development and the resources necessary to influence the further stream of events is a core characteristic of kairos constellations. Apart from technology, resource base and environmental factors, socio-psychological and epistemic factors are important influences in kairos constellations. For example, the practical and analytical capabilities of the key players, as well as their psychological dispositions to accept uncertainty and risk, influence the decision-making processes. Furthermore, the risk-encouraging or risk-adverse organisational culture of governmental authorities, firms or research organisations in which these actors are active play a crucial role. The question is, if the organisation-specific culture encourages actors to make precarious decisions, or simply rewards them for avoiding risk and uncertainty and following rehearsed strict hierarchical routines. 


\subsection{Perceptions and Narratives}

Individuals are not automatically aware of a constellation of favourable circumstances for the potential realisation of their goals. This requires active cognitive processes, which in some circumstances can involve considerable analytical effort. As Tversky and Kahneman (2020) show, human judgements under uncertainty employ heuristics which, while being highly economical and usually effective, lead to systematic and predictable errors (see also Kahneman 2012). Kairos constellations are inevitably connected with an unknown and largely unknowable future. If a favourable opportunity is to be seized in such a situation, it must be recognised as such by the responsible actors. This is by no means always the case, even in a knowledge-based society where all actors in principle should have access to a previously unimaginable amount of information. Individuals not only make such mistakes in their cognitive processes but are also influenced by different world views and epistemic cultures (Sandkühler 2009) that can facilitate or hinder the recognition of existing opportunities.

What inspires and motivates the actors (in economic contexts often the entrepreneurs) to act is, therefore, not the favourable opportunity itself, but its reflected perception by the actors. One core aspect of kairos constellations lies in the unforeseeable future development of Triple Helix constellations, especially of factors like technology evolution and market developments. Actors will develop some ideas with regard to the potentials of a university-industry innovation project, the chances of success of a newly founded hybrid organisation, or of an emergent technology. Assured knowledge about the future development of innovation processes, however, can be only available ex post. As Kay and King (2O2O) argue, the only way to prepare well for decisions under uncertainty with regard to future developments is a thorough analysis that takes into account all accessible aspects of the matter and possible perspectives on it.

As soon as the actors have formed a more or less well-founded judgment about the relevant constellation of factors and are determined to act, they are faced with the task of winning supporters for their cause. To this end, they translate their perception and interpretation of the kairos constellation into a narrative. The emerging kairos narrative, which should be as convincing as possible from the actors' point of view, serves the actors as a means to justify their own effort and attract support in their immediate environment (in their university, governmental unit, firm department, subsidiary, parent company) and in their wider environment (academic researchers, government officials, journalists, public opinion leaders). The narrative describes the situation, the goals pursued, the required resources and the actions required to realise the goals. 
There are many examples of influential narratives in the history of innovation policy (in general, on the impact of economic narratives, cf. Shiller 2019). In innovation policy contexts, most notable is Science, The Endless Frontier, a report written by Vannevar Bush and delivered to President Roosevelt in 1945. This report gave decisive impulses to science and technology policy in the United States in the decades following World War II. The Triple Helix idea is itself a narrative that originated as a metaphor in a conference in Mexico in the early 199os (Etzkowitz and Zhou 2018: 2), and has since stimulated the networking of universities and industry in many countries. Similar announcements linked to future narratives can also be found in the history of innovation policy in all market economies. Some of the European Union's programmes could be mentioned in this context, such as the launch of the Lisbon process, which set an ambitious, so far unfulfilled scientific and technological vision, or the 2030 Climate Target Plan. Some narratives may overstate the possible ramifications of development, as seems to have been the case with the proponents of nanotechnology promotion (see Section 3.2). However, Schot and Steinmueller (2018) show that innovation policy narratives related to $R \& D$, systems of innovation and transformative change have served and continue to serve the long-term framing of innovation policy in Western industrialised countries.

\subsection{Decision(s) and Their Consequences}

When a convincing narrative about the development potential of the new technology has been developed, this narrative is presented to responsible actors in firms, research organisations or in government institutions in an effort to encourage investment in the new technology. If the relevant actors respond positively to the narrative and devote resources towards the new goal, a decision process on policy action takes place that is characterised by rather idiosyncratic traits. If the narrative is principally accepted by the relevant actors, and if the matter is placed high on the priority list of all institutions involved, the actual decision is still pending. This is the point in time when decision makers can influence the stream of events (Figure 1). First, decision makers grasp the abstract opportunity to influence further development. With regard to the limited time horizon, there is a window of opportunity to achieve the goal stated in the narrative. Because of the high degree of uncertainty, an assessment of the actual costs and benefits of future technology development is only possible to a lesser extent and the deciding actors risk that the high expectations will not be met.

As soon as the decision to commit financial and human resources has been taken, relevant actors engage in activities that begin to influence the outcome 
of the narrative. Because of the underlying uncertainty, future development depends on a favourable course of circumstances and the accuracy of the original narrative. Thus, contingency is always involved in the initiated processes. The results of the activities are represented on the right sight of Figure 1. In most cases, results become apparent only after longer periods of time. In retrospect, it will be possible to assess the narrative formulated ex ante. It is rather unlikely that the target visions articulated at the beginning will literally be realised. It is more likely that a small part of a broad spectrum of different, partly negative and partly positive, intended and unintended results will emerge. This final result may be close to the original narrative, or quite different from it.

Hence, it would be wrong to scrutinise the results of actions in kairos constellations using binary logic. Dynamic action in real life often produces results that are different from the original narrative. That also applies to innovation policy and innovation processes. Although there are failures of $R \& D$ and innovation projects, the question of failure of research and innovation can be viewed from very different angles. A promising invention may be postponed for decades because the framework conditions are not favourable, while another, maybe less promising invention results in success. In other instances, researchers may draw a lot of useful experiences from a failed research project. $\mathrm{R} \& \mathrm{D}$ projects that seemed to promise rapid results may lead to a long range of follow-up projects before the desired innovations become a reality. The attempt to launch a new product on the market may fail at first, only to be even more successful at some later date, even perhaps marketed by another company (Bauer 2006: 11-18).

Decisions in kairos constellations in innovation policy are about critical choices that shape the technological development and the chances of the market players and research organisations involved over the long term and are thus suitable for establishing path dependencies. In most cases they are not reversible, or if they are, then only with great effort and at a high price. Such constellations combine short- and long-term factors under one roof. Some factors are only effective for a very limited, often short period. Others are of a "structural" nature, i.e., they persist over longer periods of time. Kairos constellations refer to the future-oriented actions of individuals, interacting players or organisations. Their results or the future chain of events of the actions of third actors that are triggered by the direct actions of the "kairos actor" are unknown in advance; they can be loosely predicted, hoped for or expected, but can never be predicted with certainty. The exante expectations tied by the actor to the sequences and consequences of his action are visible for outsiders because they are set down in a narrative orally or in written form. Ex post, 
insiders as well as outside observers can assess whether or to what extent the objectives of the original kairos narrative, which has probably been modified in its implementation process, have been realised. Empirical Research

\section{1 $\quad$ Kairos in Different Strands of Theory}

Kairos addresses a problem that is relevant for all spheres of human life, both on the individual and on the more general social level. The resonance it finds in diverse academic disciplines should be correspondingly broad. This is especially true for those disciplines concerned with the role of humans in the world, and the mechanisms and effects of their actions. As the Scopus analysis of relevant papers discussed in the beginning of this paper and the small number of publications on this topic shows, this is only partly true. The discussion below focuses primarily on those branches of research that are more or less directly linked to analyses of the innovation process. The only exceptions are historical and political studies that focus on kairos constellations. In order to provide a more coherent overview, the relevant studies are classified into four main subject areas (Table 1): systemic perspectives on innovation and its dynamics, technological and sectoral evolution, actors and the challenge of decision making, historical precedents. In all cases, we ask if the respective theoretical or empirical research approach leaves leeway for the consideration of process constellations of the type in which we are interested.

\section{Systemic perspectives on innovation and its dynamics}

If an actor wants to reasonably act in a kairos constellation, a deep understanding of the constellation's structure is required. Elements of this understanding might include the role and environment of the actor's organisation, the determinants of the constellation's development, and the interdependencies of the acting forces. The innovation literature, which focuses on systemic approaches, provides a suitable unified framework for comprehensive investigations (Lundvall 2010). In this context, the Triple Helix approach delivers an elaborated reference frame for the understanding of the major forces that influence the contemporary innovation processes and technology evolution in different regional and industry constellations (Etzkowitz and Zhou 2018; Cai 2017, 2020; Ranga and Etzkowitz 2013). 
TABLE 1 Core aspects of kairos constellations in different research domains

$\begin{array}{ll}\text { Theory / Research } & \text { Selected points of interests for understanding kairos } \\ \text { Domain } & \text { constellations }\end{array}$

(in brackets authors, titles in our reference list)

\section{Systemic perspectives on innovation and its dynamics}

Triple Helix Approach Analyses the key role of cooperation of innovative firms, academic institutions, government institutions and hybrid organisations for development in knowledge society (Cai, Etzkowitz 202O; Etzkowitz, Zhou 2018; Cai, Pugh, Liu 2017; Ranga, Etzkowitz 2013: Etzkowitz, Leydesdorff 2000); detailed analysis of the origins of the US innovation policy in the 193 os (Etzkowitz 2006)

Innovation Systems Innovation systems theory demonstrates how successful and Business Ecosystem Research innovation activity depends on the existence of a large number of diverse institutions that are closely linked by innovation oriented networks; in order to strengthen innovative capacity of a country one has to eliminate weak points in the system (Lundvall 2010; Johnson 2010); plea for a holistic innovation policy (Borràs, Edquist 2019); the basic analytical approach is also applied to regional innovation systems (Cai et al. 2017); similar system-oriented approach in Business Ecosystem Research in respect to entrepreneurial firms and their environment (Moore 1997)

Regional Economics Analyses of the determinants of the spatial structures of the economy; role of path-dependence and lock-in for spatial regional evolution (Martin 2010); windows of locational opportunity in regional economic development (Boschma 1996a,b, 1999; Boschma, Knaap 1999; Bathelt, Glückler 2018)

\section{Technological and sectoral evolution}

Science and

Technology

Evolution
Analyses the origins of technology and the mechanisms of its evolution (Arthur 2009; Basalla 2009; Vincenti 1993); central role of open-endedness, experimentality, unpredictability and uncertainty connected with genuine research processes (Rheinberger 2018); serendipity as essential element of research processes (Merton, Barber 2004); 
TABLE 1 Core aspects of kairos constellations in different research domains (cont.)

\section{Theory / Research Selected points of interests for understanding kairos Domain constellations}

(in brackets authors, titles in our reference list)

Research on sectoral
change and industrial
development

the kairos moment as argument of engineers' rhetoric (Miller 1992; Miller, Selzer 1985)

Authors analyse the chances for industrial late comers to catch-up the technological advantages of hitherto leading industrial global players and changes in industrial leadership (Lee, Malerba 2017); prominent examples of catch-up cycles and changes in industrial leadership are analysed in detail, such as the mobile phone industry (Giachetti, Marchi 2017), the memory industry (Shin 2017), and the camera industry (Kang, Song 2017)

Innovation Research Dependence of innovation processes on multitude of fac- Macro \& meso Perspectives tors; non-linear character of (most) innovation processes; supply and demand side factors in innovation processes; role of government programmes in the evolution of major new technologies, especially in the USA, allows for the reconstruction of kairos constellations at the beginnings of the development of major new technologies (Mazzucato 2014; case studies of successes and failures of such programmes in Block 2011)

Innovation Research Relationships between R\&D and innovation; role of - Micro Perspective - incremental vs. basic innovations; endemic uncertainty (Allic 2011: 243-4) of outcomes especially in the development of new technologies and of basic innovations; property rights with regard to inventions; experiences of and with innovation management, obstacles met, identified windows of opportunity in firm level innovation processes (Tyre, Orlowski 1994)

Evolutionary Draws researchers' attention to general patterns of the evoluEconomics tion of economic structures and institutions, underlining the role of knowledge, rules and (not necessarily rational) actors in processes of economic change, occasional inspiration by biological insights into development processes using the mental constructs found there as thought-generating impulses (Doper 2016; Allen 2016; Nelson, Winter 1982) 
TABLE 1 Core aspects of kairos constellations in different research domains (cont.)

$\begin{array}{ll}\text { Theory / Research } & \text { Selected points of interests for understanding kairos } \\ \text { Domain } & \text { constellations }\end{array}$

(in brackets authors, titles in our reference list)

Actors and the challenge of decision making

Microeconomics,

Behavioural

Economics

Strategy in

Management

Studies

Literature on Risk and Uncertainty
Mainstream microeconomics starts from the premises of scarcity and the rational choice of agents and analyses a broad range of economic decisions in the framework of highly mathematized models which leave no place for entrepreneurial activities and analyses of the non-linear dynamic transformations of the economy; recent behavioural economics delivers insights in individuals' behaviour that can contribute to the understanding of actions under kairos constellations (Beck 2014, Kahnemann 2012)

Management research developed the strategy concept to explain and guide the behaviour of large enterprises; starting from the 'design school' in the 195os the strategy concept was modified and defined over the last decades; delivers framework for positive and normative strategy analyses, kairos no special subject (Kiechel III 2010 for an overview, Porter 1986,1992 for the positioning school, Peters, Waterman 2015, Mintzberg 1995 for the organisational-learning school underlining the "human factor", for the role of "strategic intent" Hamel, Prahalad 2010)

While for a long time economists tended to deal with uncertainty by means of subjective probability, which was easily integrated into models of economic behaviour, Knight's approach to risk and uncertainty (1921) has recently received more attention, especially after the 2008 financial crisis; cannot be modelled mathematically, requires a high willingness to take risks on the part of the decision makers, whose decisions should be based on thorough analyses of the initial constellation (Kay, King 2020; Alchian 1950), role of 'rules of thumb' in decisions situations marked by uncertainty (Gigerenzer 2014) 
TABLE 1 Core aspects of kairos constellations in different research domains (cont.)

\section{Theory / Research Selected points of interests for understanding kairos \\ Domain constellations}

(in brackets authors, titles in our reference list)

Entrepreneurship Innovative entrepreneurs present themselves as "masters of

Research kairos constellations" by exploiting new business opportunities that they have detected or partially created themselves (Schumpeter 1947, 2006 [1912]); entrepreneurship is connected with a high level of tolerance towards risk; strategic entrepreneurship which can be a central characteristic of rapidly growing start-ups (gazelles) is also a feature of large expanding corporations (Drucker 1993; Westhead, Wright 2013; Zimmermann 2014)

\section{Historical Precedents}

Economic and Technology

History

Policy Studies, Geopolitics, Political Science, Contemporary History
Economic and technology historians explore the history of industrialisation and the economic development in the past centuries; they convey a realistic picture of the environment, mechanisms and contradictions of technological development, which also provides insights into critical development constellations in which government bodies played a decisive role (Mokyr 1992; Radkau 2008); the studies on the "projecting age" (original "Essay upon Projects", Defoe 2006 [1697]; Reder 2006; Krajewski 2008) deliver illuminating insights into an era where the search for favourable opportunities for unconventional actions became the life essence of a particular social stratum

There are power constellations that force political decisionmakers in exceptional circumstances and under uncertainty to take far-reaching decisions that have unforeseeable consequences for the country for which they are responsible (Allison 2019; Clark 2013) 
While a Triple Helix analysis primarily concentrates on how firms, universities, research organisations and government institutions interact, innovation systems research delivers a complementary view of the complex interplay of all parts of the wider innovation system (Cai et al. 2017; Johnson 2010; Moore 1997).

\section{Technology and sectoral evolution}

A number of recent studies dealing with the change of sectoral innovation systems and changing industrial leadership in different industries have analysed sectoral technological catching-up processes and development cycles under the central guiding aspect of windows of opportunity (Giachetti and Marchi 2017; Kang and Song 2017; Lee and Malerba 2017; Shin 2017). The focus of these studies, however, is less on examining specific decision-making constellations than on taking a bird's eye view of sectoral transformation processes. Analytically, the actual decision-making constellations (kairos) are characterised not only by favourable environmental conditions that lead to the development of windows of opportunity, but also by additional parameters. These are, for instance, the role of narratives and the actors' handling of uncertainty. Thus, it makes sense to treat windows of opportunity and kairos constellations separately.

In general, the research literature that deals with research processes and technology evolution transmits a central message: Although scientific research and technology development are always basically cumulative in nature (researchers and engineers building on the works of sometimes long since forgotten precursors), the actual process of advancing science and technology doesn't occur linearly, but is marked by sudden leaps and breaches (Arthur 2009; Basalla 2009). Technological progress is embedded in a multidimensional and multidirectional system comprising a multitude of interactions between many organisations and researchers widely distributed over space and time (Alic 2011: 151; cf. also Mokyr 1992; Radkau 2008; Vincenti 1993). Apart from incremental improvements of a technology and the cumulative work of "mainstream" science working under an accepted paradigm (Kuhn 2012), it is the unexpected, serendipitous and abrupt turns that play a decisive role (Merton and Barber 2004; Rheinberger 2018).

Even though most innovation policy programmes still follow the idea of a linear, steadily advancing technology evolution and linear progress remains undoubtedly always a part of innovation, innovation research has long abandoned the idea that the "linear model of innovation" is the dominant pattern of innovation processes (Godin 2017). The open, incalculable paths of innovation 
processes and technology evolution are mostly complex in nature and are characterised by leaps, feedback loops and periods of relative stagnation as well as substantial acceleration. In this context, kairos constellations can play a key role, as was discussed in the last section. Thus, it is no coincidence that actors explicitly use kairos as argument in the rhetoric narratives of their activities (Miller 1992; Miller and Selzer 1985).

\section{Actors and the challenge of decision making}

Neoclassical microeconomic theory and the ensuing rational choice models are based on the central assumption of a rational actor who disposes at full information about all relevant circumstances. In these approaches, there is no place for the analysis of dynamic changes and far-reaching decisions that do not follow the restricted patterns of behaviour prescribed by a fictitious world of equilibria. On the contrary, recent developments of behavioural economics are primarily interested in actual behavioural patterns of individuals in realworld situations. Behavioural economics is helpful in the analysis of single decision situations (Beck 2014; Kahnemann 2012). However, research in this field does not scrutinise decision-making situations of the type we are interested in.

In contrast, the increased attention devoted by the research literature to the role of different manifestations of uncertainty in economic and technological development processes strikes at the core of kairos constellations, radical uncertainty being a central element of many decision constellations (Alchian 1950; Gigerenzer 2014; Kay and King 2020; Knight 1921). The same applies to entrepreneurial research (Drucker 1993; Schumpeter 1947, 2006 [1912]; Westhead and Wright 2013; Zimmermann 2014). Entrepreneurs who are engaged in rapidly growing firms must make strategic decisions in a market environment that is characterised by a high degree of uncertainty, and that are often irreversible.

Management research seems to provide a better theoretical framework for analysing actual decision-making in firms than microeconomic theory. Indeed, it delivers interesting starting points for the analysis of kairos constellations. This refers especially to the part of the management literature that concentrates on the "human factor", i.e., the role of individuals and their interactions in decision situations. The role of individuals, with all the imponderability connected with it, was a central controversial point in the strategy literature between the positioning school, led by Porter, and the organisational-learning school for which Mintzberg is an outstanding representative (Hamel and Prahalad 2010; Kiechel III 2012; Mintzberg 1995; also, Peters and Waterman 
2015, as an opposite pole to the positioning school). While Porter delivers an excellent analytical framework for the study of economic environments of clusters that is relevant for analyses of kairos constellations in cluster development, his approach does not highlight the role of human decision makers in cluster policy. Other streams of the strategy literature explicitly address the key role of acting individuals in the strategy formulation and execution processes. The focus of the short-lived business reengineering school on the idea that "everything must change here and now" (Hammer and Champy 1995) is reminiscent of the kairos motif, although it does not address the deterministic elements of the structural context, the principal openness of the decision situation, and the role of uncertainty.

\section{Historical precedents}

Political history provides many examples of kairos constellations where responsible actors' decisions initiated long-term path-dependent developments of international relations or the development of nations and regions (Allison 2019). In the field of economics, a wide range of episodes in the history of pre-industrial UK and France from the 17th and 18th centuries was marked by the trials of undertaking middle- and upper-class individuals to search for and realise profit-promising projects of any kind in an early capitalist spirit (Defoe 2006 [1697]; Reder 2006; Krajewski 2008 [2004]).

Overall, none of the mental constructs mentioned has produced a ready key to the analysis of our research subject. However, each of the different disciplinary approaches can contribute to an understanding of the kind of decision constellations in which we are interested. An interdisciplinary perspective is suited to produce a more complete picture of the phenomenon to be analysed.

\subsection{Empirical Traces of kairos Constellations in the Evolution of the Triple Helix}

Recent innovation policies presented in the political arena offer a variety of reference points for the role played by kairos constellations in the evolution of a Triple Helix. In every case, an external challenge or opportunity directs the decisions and actions of protagonists - an individual or groups of responsible individuals from government institutions, academic organisations and firms - that initiate a technology project or a specific sectoral development. Of course, major policy interventions initiated by the government in research and innovation processes attract the attention of external observers. Governmental interventions can occur at the national level, as well as the regional level, in which case the intervention falls under the competency of 
local authorities. Interventions can also be applied to specific technologies, industries or enterprises.

We focus on three examples drawn from US innovation policy. These examples are characterised by: (i) a fundamental reorientation of American policy during the decades from the Great Depression to the years immediately after the Second World War, (ii) unexpected long-term consequences of this reorientation with regards to Triple Helix arrangements, and (iii) the way a visionary yet nebulous technological narrative about an emerging technology was transformed to mobilise Triple Helix actors for joint research efforts.

\section{The origins of proactive innovation policy in the USA}

Although it could be argued that the origins of US innovation policy go far back to the foundation of Land Grant Universities in the 19th century, a national innovation strategy emerged much later. Roosevelt's New Deal programmes, in response to the Great Depression, drastically altered the climate for the later acceptance of a national innovation strategy, but did not immediately lead to its formulation. Yet, the New Deal policy brought about at least an acceptance for the core of today's research system that is based on private-public partnerships and emerged already in the period after the Great Depression.

As Etzkowitz (2012) and Etzkowitz and Zhou (2018) show, an early sciencebased strategy was developed at the regional level in the New England states, but at the time of the Great Depression not adopted at the national level. These regional efforts became the basis of a national innovation strategy in response to ww II. Strong impulses came from the Manhattan Project, which was initiated in response to technological threats from Nazi Germany and Japan. Individuals, such as Karl Compton (President of the MIT) and Vannevar Bush, played a key role in laying the foundations for what initially was a regional innovation strategy based on the Triple Helix (Etzkowitz and Zhou 2018). After the war, the decision was made at the national level to massively invest in a system of research laboratories managed by the state, and the intense expansion of scientific and engineering expertise in federal agencies. The apparent goal was to achieve global leadership in strategically important fields of technology (Block 2011: 6-8). The development of nuclear carrier systems in the Soviet Union in the 1950s gave the USA no choice but to expand its relevant military research, even though it had successfully taken advantage of a window of opportunity already in the mid to late 1940 os and early 195 os.

In contrast to its erstwhile geopolitical rival, the UssR, American innovation policy relied heavily on a close partnership between government institutions, research organisations and private industry in the process of building 
technological capacities. Long-established companies, university spin-offs and start-ups of all kinds played a core role in this development, as well as innovation-oriented universities, who were often strongly involved in practical issues. The emerging American Triple Helix was shaped by government involvement intended to stimulate the inventiveness of academic institutions and the innovative forces of private businesses. The comprehensive system of research institutions developed at that time and the dynamic Triple Helix innovation network that is constantly adapting to new challenges still exist today. After a post-Cold War phase of reorientation (Boutin 2013), the network is still adapting to changing geopolitical realities. From its very inception, fundamental kairos decisions made over the course of over half a century were responsible for shaping the research and technology system in the USA today.

\section{The unplanned invention of the internet}

One might think that the USA, with the expansion of its public-private research system in the 1940s and early 1950s, was far ahead of other powers in the development of usable military technologies. However, the Sputnik shock of 1957 left responsible politicians with a great sense of consternation. Although the shock of American decision-makers triggered by unexpected Soviet advances was probably exaggerated, there is no doubt that the administration's reaction was prompt and determined. A remarkable element of the rapidly initiated efforts to push forward militarily relevant technologies was the establishment of the Defense Advanced Research Projects Agency (DARPA) in 1958. DARPA was funded from the military R\&D budget, and was based on an unconventional model of technology promotion that was probably unique at the time. The fundamental idea was that all the individuals involved in DARPA would be given the time and resources for "blue-sky thinking" (Mazzucato 2014: 76), the chance to develop new ideas and unconventional projects without restraints from the outside.

DARPA developed remarkable technical devices that became the basis of the modern IT sector (Block 2011; Mazzucato 2014; Chandler Jr. 2005). IT firms transformed these inventions into marketable products. The creation of the Internet is one of several developments that can be attributed to DARPA. When DARPA was founded, there was no narrative suggesting that a worldwide network that could connect millions of computers should be created. While the initial idea for a distributed communications network that could operate in case of a nuclear attack was developed in the 1960s by a researcher at RAND (Research and Development) (Mazzucato 2014: 104-105), the original version of what today is called the Internet was initiated by DARPA in 1969 as ARPANET 
(Chandler Jr. 2005: 170). In the subsequent decades, the hardware and software needed to develop a global communication system were successively developed, and in the 199os the World Wide Web was launched. Although other nations would probably have developed a similar system at some point in time, the fact that actors in the USA reacted successfully to a kairos constellation due to the establishment of the DARPA gave this country early technological leadership in this field.

\section{The US nanotechnology initiative}

The genesis, progression and results of the US government's development of its nanotechnology programme followed a very different path when compared to its IT programmes. While the IT programmes were primarily driven by national security issues and the military, the nanotechnology program has its origin in basic academic research. "Nanotechnology" is the generic term for diverse technological applications that have little in common apart from focusing on the "nano" dimension. The scientific community's high, although somewhat vague, expectations for nanotechnology were nourished by the visions of individual researchers, and were only partly rooted in scientific knowledge (Schumer 2009).

The US government, anticipating a leap in nanotechnology development, reacted positively to suggestions from prominent scientists. The organisational foundations for a proactive, mission-oriented programme to promote nanotechnology in the USA were laid in the second half of the 1990s. In 2000, the "National Nanotechnology Initiative" (National Science and Technology Council 2000) was initiated (Mazzucato 2014). Although nanotechnology development is primarily driven by academia, the same formula used to promote the development of the internet was employed: close cooperation between firms, government laboratories and academic institutions, as well as creative leeway for individual research. Criticism of the lack of a publicly communicated narrative about the significance of nanotechnology (Newfield 2011) has not seriously impeded the research efforts of Triple Helix actors in this area.

It is still too early to assess the results of the respective programmes that were initiated in most major industrial and industrialising countries during the past two decades (for China, see Appelbaum et al. 2011). Presently, there are many indications that a good deal of the expectations set by experts in the development potential of nanotechnology could become true in the near future. Those countries not participating in the efforts to develop the new technologies could fall behind in this field. If this happens, countries like the 
USA and China that developed nanotechnology programmes early on, have seized a kairos moment.

The abovementioned examples show that there is a plethora of kairos constellations in innovation policy. With the global environmental challenges of contemporary societies, the ascendance of artificial intelligence and robotics and the increasing importance of close existential ties between science and technology evolution the three strings of the Triple Helix - enterprises, governmental authorities, academic institutions - face serious challenges that can only be overcome in Triple Helix constellations.

\section{Kairos in Cluster Policies}

\subsection{Kairos, the Triple Helix, and the Rationale of Cluster Policy Programmes}

Thus far, we have looked at kairos constellations in innovation policy from a theoretical perspective and discussed historical examples. In this section, we are looking at a policy area - cluster policy - that still enjoys popularity in all highly developed economies. A discussion about cluster policy might seem to be far removed from the idea of kairos. However, the aim that underlies cluster policy interventions is apparently that a development of an industrial cluster that has come to a standstill - for whatever reason - should be brought back into balance by imposing a suitable impulse from outside. It is therefore worth taking a closer look at the theoretical justifications for cluster policy and their explanatory power for the timing of cluster policy measures.

There are different approaches that can be used to justify cluster policy programmes. The approach rooted in neoclassical economic theory considers different kinds of market failures as a core justification for cluster policy intervention. The arguments put forward here reach from limited appropriability of newly generated knowledge and uncertainty of later applicability of research results, to information asymmetries in capital markets (Borrás and Edquist 2019; Edler and Fagerberg 2017; Vicente 2016). Innovation research which is often based on an innovation system approach, refers to deficits of the regional innovation systems, that is to system or network failures and thus resorts to a concept analogous to market failure. Porter (1998a, 1998b), focuses his argument on the realisation of competitive regional advantages by applying lines of thought from microeconomic theory to spatially defined social entities. ${ }^{6}$ While the research literature that is based on these approaches addresses the question of whether and under what circumstances cluster emergence and/ 
or development should be promoted, the decision-making constellations that could set such promotion in motion are usually not addressed.

The Triple Helix model and the kairos metaphor provide a suitable approach to analyse not only the basic constellation of actors participating in technologyoriented cluster programmes, but also the timing of cluster policy projects. Cluster programmes, like the closely related programmes that promote networks, increasingly aim at creating and/or expanding links between academic and research institutions, incumbent firms and start-ups, with state or staterelated intermediate organisations that usually act as third parties in the emerging partnerships. In this framework, it is rather straightforward to ask about the right timing of cluster policies.

Cluster policy interventions occur within a fixed time frame and must confront an industrial and technological environment that is defined by certain temporal and spatial conditions. The challenge for cluster policy is to identify the right actors to promote, at the right time and in the right place. Thus, the cluster policy concept defines a general policy framework that is realised by concrete political action. The search for, the identification and the mobilisation of kairos constellations in cluster promotion is a legitimate part of practical policy. This raises the question of whether cluster research has revealed insights with respect to relevant entry points for successful policy action.

\subsection{Cluster Life Cycle Theory and kairos Constellations}

Cluster life cycle theory is a branch of cluster research literature that at first glance seems to provide a convincing starting point for the identification of kairos constellations in cluster policy. In fact, an adjusted concept of cluster life cycles that allows for a wider range of possible development trajectories proves to be rather suited as a model to explain how kairos constellations arise.

Industrial clusters have, in most cases, developed around a specific industrial sector, or closely related industries connected by supply and demand linkages. The emerging industrial complexes are complemented by a range of service companies and a wide range of infrastructural and public service facilities as well as educational and research organisations. The concentration of cluster structures on one industrial sector or a complex of similar industries implies a close link to a field of technology. This has led cluster researchers to assume that clusters, like technologies and industries, go through life cycles that can be represented schematically by a sequence of development stages (Audretsch and Feldman 1996). Hence, life cycle theory assumes that industrial clusters go through a phase of formation or emergence, a phase of sustainable growth, a phase of stabilisation, and a phase of more or less prolonged 
decline, which might lead to their total disappearance (for a literature survey, see Bergman 2007). The idea sounds tempting that a phase of the cycle, for instance, the formation phase, offers the best possible entry point for policy support of cluster development. Cluster policy would then only have to watch for the right moment to intervene in a supportive manner.

There is empirical evidence that at least some clusters go through stages of development, which can be described in life cycle categories. Particularly impressive as an example of industrial clusters that have gone over nearly two hundred years through a complete cycle from birth to complete disappearance are the old industrialised areas of the coal-steel complex in the UK, in the North-East of the USA and in Central and Western Europe. However, there are considerable differences between industrial clusters. Thus, the idea that the stages of a cluster's life cycle open up different opportunities for external development impulses (state subsidies) that is often connected with the life cycle concept (Brenner and Schlump 2011), requires modification. Dalum et al. (2005) offer a more differentiated perspective on the commonalities and differences of cluster life cycles. They show that shifts in technological life cycles can create opportunities to further the development of incumbent clusters, and also to encourage the emergence of new clusters. Martin and Sunley (2011) argue that the cluster life cycle model has serious limitations that severely limit its cognitive value. Instead, they present an "adaptive cycle model" which they adopted from evolutionary ecology.

Although biological metaphors like life cycles are heuristically fertile, they can reflect economic and social realities only to a limited extent. ${ }^{7}$ The specific technological field and the path of development of the relevant technology domain are more critical than life cycle metaphors in determining the development of technology-oriented clusters. Other influencing factors that do not fall under the term "technology" are the development of global markets, abrupt changes in regulatory influences by the state, or the personal lives of central cluster players. In many cases these influences are completely independent of the technological profile of the corporate department located in the cluster. Subjective factors, such as the willingness of leading managers of a large global company to become involved in a regional cluster, or the willingness of cluster players to get involved in joint projects that can bind the capacities of their own organisation for a long period of time, are other influencing parameters.

Against this background, there may be critical challenges in every stage of cluster development, on which the cluster actors or external actors who influence on the development of the cluster, have to respond, that are relevant criteria for kairos constellations in cluster development. Key factors are 
fundamental changes in market conditions for the cluster's products, the emergence of disruptive technologies or dramatic changes in the cluster's business population. Such challenges might appear in any phase of a shorter or longer cluster life cycle. At the same time, they can - in an advanced stage of cluster development - initiate a new cluster life cycle.

\section{3 "Clustering" of the Economy vs. kairos Clusters in German Cluster Policies}

In this section, we look at the role of kairos constellations in the practical application of cluster policy in Germany. The discussion is based on three types of sources: interviews conducted by the authors as a part of various research projects with government officials responsible for cluster promotion programmes and stakeholder of these programmes, an analysis of government publications on cluster policy, and several academic studies (Beck 2014; Dohse 2000, 2007; Dohse and Staehler 2008; Fornahl et al. 2010; Fornahl et al. 2012, Fornahl et al. 2015; Frommhold-Eisebith 2014; Kiese 2012, 2014, 2017; Rothgang et al. 2017; Uyarra and Ramlogan 2016; Wolf et al. 2019).

Since their introduction in the early 1990s, German cluster policies have developed along similar lines to their counterparts in other European countries and in the USA. "Cluster policies" is a generic term that is used for a wide range of measures taken by the state to promote structural change in the local economy, and to foster the development and dissemination of advanced technologies. Broadly defined, cluster policies include any measures taken by government agencies that aim to support the formation of new clusters and promote existing ones. As mentioned above, the diffusion of these policies was essentially influenced by the writings of Michael Porter (1986, 1992, 1998a, 1998b, 1999), who examined the competitive forces at work in a region from a systemic perspective and, on this basis, developed concepts for strategic action by both companies and state authorities.

German cluster policies comprise, on the one hand, well-funded cluster programmes aimed at promoting the research and economic activities in new technologies or markets in spatially defined emerging or established clusters of related firms, research organisations and service institutions. On the other hand, a large number of mostly smaller programmes aimed and still aims at establishing and promoting cluster initiatives in all parts of the country. Most of the programmes that belong to the former group are carried out under the aegis of the federal government, the programmes that belong to the latter group are usually initiated by the 16 federal states and co-financed by EU framework programmes. The boundaries between cluster support and support 
for innovative networks, which aims to increase cooperation between large companies, SMEs, academic institutions and hybrid organisations, are fluid (Kiese 2014: 11).

From the outset, cluster policy has operated in terrains already occupied by other structural policies, such as regional policy, industrial policy, or technology policy. Eventually, cluster policy took over certain essential tasks of conventional structural policies. The objectives underlying specific cluster programmes are diverse. In addition to the narrow goal of cluster promotion, other goals are associated with innovation policy, regional policy, climate policy, or health policy. Today, almost every policy programme related to technological, regional or industrial development contains a more or less pronounced cluster or network component.

The general orientation of German cluster policy has always been caught in a field of tension between balancing regional development and growth policy goals. In the course of the increasingly strong emphasis on the promotion of new technologies within the framework of cluster policy, the accents have clearly shifted in favour of growth orientation. In this process, the basic idea of the Triple Helix was increasingly taken up, even if this was not explicitly propagated under the keyword "Triple Helix" in the respective programmes.

Cluster support was strongly influenced by a mechanistic understanding of cluster policy that is quite distant from the views commonly held among cluster researchers (Kiese 2014: 176f.). Clusters were often not primarily conceived as an empirical phenomenon that emerged as a result of spontaneous market processes, but as the result of a mediation among cluster actors by the authorities. Thus, clusters were seen as something to be "created" and the newly founded cluster initiatives and the corresponding actual clusters were not distinguished from one another. ${ }^{8}$ In most cases, the top-down formation of cluster initiatives suggested by the state authorities was based, if at all, on superficial analyses of the industrial clusters actually existing in the state territory. This resulted in a more or less comprehensive, undifferentiated cluster support that extended to all regions, whereby the financial resources distributed were in most cases - with the exception of the financially strong state of Bavaria - rather modest. The resulting broad "clustering" of the economy on the state level led to an "inflation" of cluster initiatives criticised by some authors (Frommhold-Eisebith 2014; Kiese 2014). In these cases, cluster policy resulted from the mechanical transfer of a concept developed elsewhere and took place independently of the existence of any kairos constellation. Of course, this approach to "clustering" is not in line with the basic considerations and implications of the Triple Helix model. 
The situation was different in the case of a minority of mainly federal cluster programmes that focused on the careful selection of technology clusters for funding on the basis of a specific constellation of circumstances within and outside the cluster. This could be the emergence of a new technology, or a dynamic development in a new market segment. The underlying idea of these programmes was kairos, taking advantage of the irrefutable chance and the unique, favourable, time-bound opportunity. These German cluster programmes are of central importance due to their financial resources and their significance for the country's cluster policy. In the following, we deal with the example of biotechnology cluster programmes. Another German cluster programme which could be viewed under the "windows of opportunity" aspect, is the Leading-Edge Cluster Competition (BM BF 2007; Rothgang and Lageman $2017,{ }^{9}$ Rothgang et al. 2019).

\subsection{German Cluster Promotion and Triple Helix Structures in Biotechnology}

The development of biotechnology, ${ }_{10}^{10}$ which emerged in the course of recent technological evolution, is based on close cooperation between economic, academic and governmental organisations. Like other science-based technologies, it embodies the Triple Helix. Advances in molecular biology, largely due to American basic research in this field, have opened up extraordinary scientific and technological opportunities for the development of novel drugs and diagnostics that could sooner or later provide a decisive impetus in the fight against cancer and other diseases. The biotechnology innovation system in the United States is the result of a long chain of political decisions and institutional developments. The resulting system is well prepared for the task of mobilising entrepreneurial forces to take advantage of the economic opportunities that continue to develop in this field (Cockburn and Stern 2010: 37).

In the USA, substantial federal funding of both basic molecular biology research and biotechnological applied research (Cockburg and Stern 2010: 4; Mazzucato 2014: 67-71) complemented favourable framework conditions. Basic research in universities and in the National Institutes of Health created a solid foundation for applied research in biotechnology, from which the dedicated biotech companies continue to benefit today (McMillan et al. 2000). The favourable framework included the willingness of academic researchers to become involved in start-ups, some of which later developed into dedicated biotech firms, a well-functioning regulatory and patenting system, and the autonomous self-organisation of the publicly financed research institutions that also left room for "blue sky research". Other important favourable factors 
are the existence of a developed Venture Capital (vc) sector and an extraordinarily high demand for effective biopharmaceuticals (Cockburn and Stern 2010). Although the returns on the invested research funds have generally been lower than expected, the flanking public support has ensured the development of an efficient Triple Helix structure. This is characterised by large pharmaceutical companies, small and medium-sized dedicated biotech firms, research institutes and universities that are closely linked with each other.

Although the potential of using biotechnology in the development of medical therapeutics and diagnostics was recognised in Germany in the 1970s, (Canzler et al. 2011), the German biotech sector was slow to develop. Even by the mid-199os, this sector was insignificant compared to the US (Giesecke 20oo: 207), and was also clearly behind some other European countries, such as the UK. As Giesecke (2000, 2001) shows, this inertia could largely be explained by specific weaknesses of the German innovation system that were detrimental to the development of emergent knowledge-based technologies. The pharmaceutic sector was dominated by big corporations that had only weak ties with academic research. There was no established tradition of academic entrepreneurship by university researchers. Most researchers were dedicated to basic research and had little interest in applied research questions. The Triple Helix, which is crucial for the development of these technologies, could not achieve its full potential under the traditional focus of the German innovation system, namely, the development of conventional high-tech areas such as mechanical engineering or automotive construction. These areas are characterised by a gradual accumulation of knowledge, and incremental improvements in products and production processes. However, this is changing today under the influence of the increased importance of IT technologies.

Recognising the need to compete with the dynamic evolution of US biotech sector, the German government set up relevant funding programmes. Gradually, it became clear that the development of a thriving biotech sector would require far more than direct government funding. In the 199os, German technology policy underwent a re-framing that resulted in today's broader understanding of innovation processes and the role of policy. In the specific case of the biotechnology sector, this meant that the attention of policymakers went beyond merely financial support. Policy measures were initiated that ultimately resulted in the restructuring of the biotechnological innovation system (Wieland 2011: 259). These measures included promoting the development of a vc sector, propagation of a "third mission" to universities hitherto unknown in the German academic landscape, promotion of knowledge-transfer between universities and enterprises, and the introduction of a German counterpart to the Bayh-Dole Act. 
The cluster funding of the biotech regions was intended to send a signal that German policymakers were determined to "catch up" with countries that were leaders in biotech development. This gesture, which was rather unusual for German politics, was directed equally at all Triple Helix actors: the business community, universities, research organisations and regional and local government authorities. This new approach relied on the initiative and cooperation of all participants in a spirit of partnership that corresponded to the basic idea of the Triple Helix model. Regardless of the actual financial contribution of the cluster programmes to the development of the biotech sector, which make up only a part of German public biotechnology funding, these programmes were also symbolically important for German innovation policy.

The Federal Ministry of Education and Research began its cluster programmes initiative by launching two biotech competitions: BioRegio ${ }^{11}$ and BioProfile $^{12}$ (cf. also Figure 3). Both competitions differed considerably in terms of modalities, but followed the same basic principle: a competitive public tender, selection based of an examination of applications by an expert jury, considerable funding awards that extended over a period of several years. The aim was to allow biotech start-ups, which mostly originated as spin-offs from a university department, to work on their biotech projects without the need to create short-term revenues. The specific project funding was always integrated into a joint regional cluster development project, in which the local universities, companies and state organisations were to participate alongside the funded start-ups.

The regional Triple Helix structures established in the biotechnology sector benefited from several successive programmes. Among the 15 winning

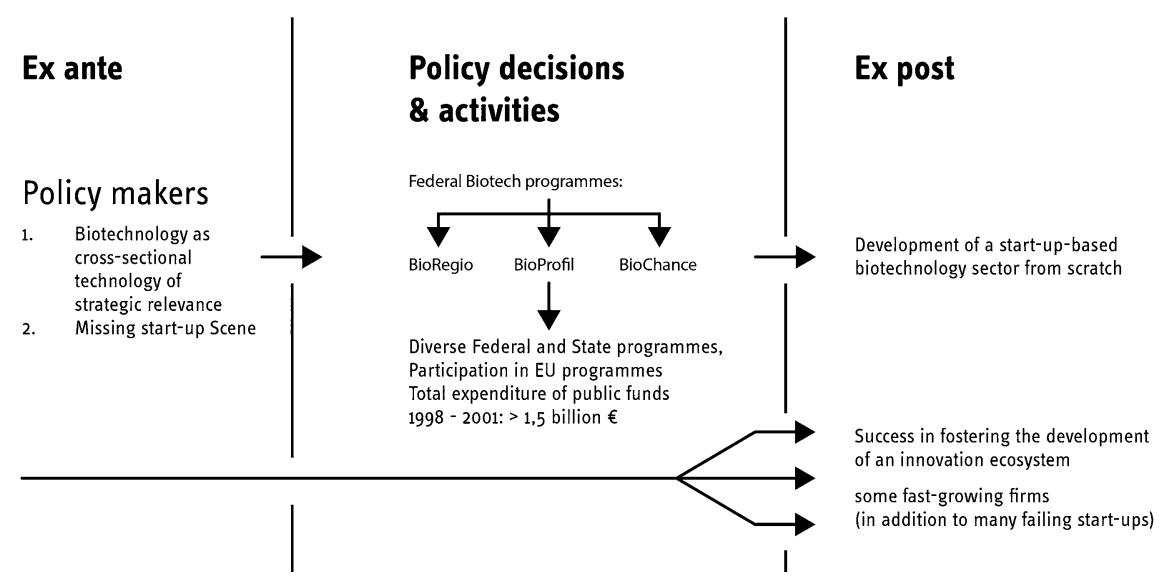

FIGURE 3 The case of the German biotechnology cluster programmes SOURCE: AUTHOR'S OWN DEPICTION 
programmes of the Leading-Edge Cluster Competition of the Federal Ministry of Education and Research (2008 to 2013), there were three bioregions specialising in personalised medicine, each of which benefited from approximately $€_{40}$ million in funding. The federal BioChance and BioChance Plus programmes specifically addressed the financial needs of SMEs specialising in biotechnology. In addition to the public funding received by start-ups, incumbent firms and research organisations involved in these programmes, other biotech firms which were not financed from these programmes benefited from the sectoral funding programme. ${ }^{13}$

There is clear evidence from expert evaluations that the distribution of public funding in the BioRegio Competition had a substantially positive effect on the development of biotech start-ups (Dohse 2000, 2007; Dohse and Staehler 2008). In 1995, there were 70 biotech companies in Germany, a decade later there were around 6oo, a higher number than in other European countries. This apparent success led the Ministry of Research to claim that the BioRegio initiative "opened the door to the successful use of biotechnology in Germany" (BMBF 2004b: 287). Considering the weakness of the German VC sector and the lack of alternative sources of financing, many of the still existing biotech start-ups that were founded during the last decades would probably not have survived the long dry spell of several years before generating their own modest revenues without public funding. We estimate that the aggregate total of subsidies that have been allocated to the biotech sector since 1995 amounts to well over $€_{1.5}$ billion. Biotech firms in Germany have benefited substantially from these state subsidies.

In retrospect, the generous biotechnology funding - which marks a readjustment in German structural policy - shows that German cluster policy was a timely and successful reaction to a considerable competitive and technological challenge (Figure 3). Given the early advanced state of development of Triple Helix structures in biotechnology in other industrialised countries, it would have seemed very unlikely that two German companies, BioNTec and Curevac, would be among the top vaccine developers in the corona crisis 2020/21. The decision taken by policymakers in the mid-199os to get involved and to forge a new trajectory was decisively influenced by experts from science and industry. It was supported by the close cooperation of existing companies, academic institutions and representatives of the emerging start-up scene, and can be considered a German example of joint initiatives under the umbrella of the Triple Helix. The resulting development of Triple Helix structures in biotechnology were neither foreseeable, nor in any sense predictable at the inception of government sponsored initiatives. In addition to the emergence of a national biotechnology industry composed mainly of start-ups, 
institutionalised research structures developed in universities and public research institutes that - similarly to the USA -fulfil an important complementary role in the German innovation system today.

\section{5}

\section{Summary and Discussion}

Starting from the observation that kairos constellations are ubiquitous in human individual and social life the research question of this paper is how kairos moments were dealt with in the Triple Helix and the wider innovation policy research literature. In doing so, we take a look at the extent to which various disciplines have encountered kairos constellations, even without classifying it under this label. We develop a conceptual framework for Kairos constellations and apply it on an example from the Triple Helix - based cluster policy.

We define a kairos constellation in the development of the Triple Helix as a temporarily existing opportunity for a group of responsible actors to take advantage of a fortunate coincidence of favourable circumstances in order to realise a shared target. Decisions made in a kairos moment can have a lasting impact on the development of an organisation, a technology, or a policy area, and are triggers of path dependence. Kairos constellations are inevitably associated with uncertainty about future developments, and entail considerable risks for the involved actors.

Kairos constellations occur repeatedly in the course of the development of the Triple Helix. An empirical study of the New England states' response to the Great Depression shows that actors actively responded to contemporary economic and technological challenges in a situation that can be coined as kairos constellation, though the term kairos was not used in this study (Etzkowitz 2012; Etzkowitz and Zhou 2018). Similarly, studies on technological catch-up cycles and changes in industrial leadership explicitly address the issue of windows of opportunity in the development of sectoral production and innovation systems (Lee and Malerba 2017; Giachetti and Marchi 2017; Shin 2017).

Many academic disciplines contribute to the understanding of kairos constellations, albeit to widely varying degrees. Boschma's regional economic studies (1996a, 1996b, 1999; Boschma and van der Knaap 1999), which identify "windows of locational opportunity", come close to what we define as kairos constellations, although the actor perspective (organisational background, mental models, socio-psychological dispositions) does not play a central role in his concept. Kairos constellations play a decisive role in entrepreneurial research that follows the tradition of Schumpeter (1947, 2006 [1912]). Schumpeter was convinced that identifying and seizing unexpected opportunities is the 
essence of innovative entrepreneurial activity. The approach of microeconomic theory is, however, far from capturing decisions in kairos constellations, although recent developments in behavioural economics as well as the more recent literature on uncertainty and risk provide valuable insights into mechanisms that underly the behaviour of decision makers in critical situations. The research literature on science and technology evolution (Arthur 2009; Basalla 2009) provides an excellent basis for developing a deeper understanding of the technological processes that politicians, entrepreneurs and scientists are confronted with in their decision making.

Our key message is that Triple Helix researchers need to systematically study kairos constellations because they are a critical force in the evolution of innovation systems which has not yet been systematically researched. We assume that the kairos model could be elaborated in more detail in future works and applied in empirical studies of innovation policy. We hope to firmly place the idea of kairos moments in the discourse on Triple Helix dynamics.

This paper has its limitations and reveals possible avenues for continued research. It would be worthwhile to scrutinise whether there are typical reaction modes of decision-makers in the Triple Helix to kairos constellations depending on national traditions of universities, industrial companies, and government organisations. Although current political responses to the challenges of climate change appear at first glance to be very similar, national science systems are mobilised to varying degrees to develop the required new climate technologies, a highly salient task for the Triple Helix (Mazzucato 2014: 141-164). Furthermore, new insights might arise if kairos constellations and Triple Helix configurations were used to examine the reactions of the industrialised countries to the challenge of artificial intelligence.

Without doubt, the challenge of uncertainty in innovation policy and the role of cultural differences in dealing with kairos constellations deserve more attention. Although progress has been made in recent decades (Kay and King 2020), economic theory and innovation research should tackle the issue of uncertainty, especially considering the fact that technological evolution is characterised by a high degree of uncertainty. While minor incremental improvements of an existing technological solution are calculable and can be integrated in the planning processes of firms, abrupt changes of technology present them with major challenges that are beyond the predictability of any established planning framework. The research literature has coined the term "ambidexterity" to describe the capability to meet these challenges without disrupting routine activities (see, for instance, Wolf et al., 2019). This concept originally addressed the behavioural patterns of firms, but it is obvious that it also applies to Triple Helices and the research organisations and government 
authorities involved. In a national framework, these are primarily the ministries of innovation and technology, in the framework of the European Union the European Commission. A promising avenue for research could be to analyse how and why the innovation policy of the European Union and the European national states differed from that of the US in the decades after WW II (for the latter Block and Keller 2011; Etzkowitz and Zhou 2018).

At a time when the global political and economic balance is shifting rapidly, it seems appropriate to look at how the issues that have been discussed here are handled in major non-European cultures. Kairos constellations show a certain eligible affinity (Wahlverwandtschaft) to the Shi of Chinese philosophy (no exact western translation available, rough approximation: momentum, potential energy). Shi plays a major role in Chinese strategic thinking (Allison 2019: 148-149; Jullien 2006, 2008), although to our knowledge the contact points between the ancient Greek and the Chinese concept have not been examined in western sinology. This could be a starting point for the investigation of different cultural imprints on innovation policy. As the difficulty of reproducing the experiences of Silicon Valley in other cultural contexts indicates (Cai et al., 2018: 252), the role of cultural factors for learning from foreign role models has so far been understood only to a limited extent. This also becomes clear, when we confront studies on the Silicon Valley's development (Ezkowitz and Zhou 2018; Keese 2014; Saxenian 2006) and Germany's obvious difficulty to imitate this successful example (see Kiese 2014). Although there are indeed examples of policy makers in other countries who successfully conveyed experiences from Silicon Valley to other countries (see Saxenian 2006 on Israel, Taiwan and Shenzhen), many comparable projects have not succeeded.

\section{Acknowledgements}

We thank Martina Böhmel and Ida Zinke for their assistance in literature search and completion of the manuscript. The publication of this article was funded by the Open Access Fund of the Leibniz Association.

\section{Notes}

1. Basic ideas for the present paper were presented in a power-point presentation for the virtual Triple Helix Conference 2020.

2. See also the recent semi-secularized version in Benjamin's work (Benjamin 2007; Konersmann 2007). 
3. "Kairos". Merriam-Webster.com dictionary. Available at: https://www .merriam-webster.com/dictionary/kairos (accessed 3 March 2021).

4. The search was carried out on 24 February 2021.

5. See Wikipedia on kairos: https://en.wikipedia.org/w/index.php?title _kairos\&oldid_940409368 (accessed 7 August 2020).

6. Some other authors (e.g., Duranton 2011; Hospers et al. 2008) argue that there is no rational justification for cluster policies by targeting weak points of the usual chains of argumentation.

7. The biological life cycle metaphor is often used in the social sciences, for example in the research about the long-term development of corporations or family businesses. Carroll and Hannan (2000: 359) point out, however, that although the concept of organisational life cycles may apply in individual cases, it only gives a distorted impression of the longterm development of organisations and is not suitable for providing a useful basis for descriptive, let alone causal models of organisational change.

8. The relationship between the clusters and the cluster initiatives that (sometimes supposedly) represent them does not seem to have been satisfactorily solved so far in cluster research with regard to the inevitably arising governance and principal-agent problems.

9. Rothgang and Lageman (2017) explicitly address the question of windows of opportunity with regard to the selection of "Leading-Edge Clusters" without looking for a theoretical foundation of the "windows" concept.

10. The discussion focuses on medical, the so-called red biotechnology.

11. BioRegio Competition: The public announcement to tender for this competition took place in 1995. Seventeen applications were received from different parts of the country. Finally, four model regions were selected. The public funding of 90 million $€$ for each region was started in 1997 and extended over 5 years (cf. вм вғ 2004a: 6-9, Figure 3).

12. BioProfile: The second competition, announced in November 1999, focused on the translation of biotechnological knowledge into product and process innovations. Initially, 30 regions took part, 20 of which were shortlisted. The jury awarded three regions, which together received 5 o million $€$ in state subsidies (cf. вм вF 2004a: 6-9, Figure 3).

13. The Federal government's national technology policy distinguishes between programmes that promote specific technologies and non-sectorspecific programmes such as the cluster programmes that pursue broader objectives. General R\&D projects are funded under both programme types. Emerging biotech firms were also funded, to varying degrees from state to state, by state-specific programmes. 


\section{References}

Alchian AA (1950) Uncertainty, evolution, and economic theory. The Journal of Political Economy 58: 211-222.

Alic JA (2011) Everyone an innovator. In: Block F and Keller MR (eds) State of Innovation. The US Government's Role in Technology Development. New York: Routledge, 236-26o.

Allen PM (2016 [2005]) Understanding social and economic systems as evolutionary complex systems. In: Doper K (ed.) The Evolutionary Foundations of Economics. Cambridge: Cambridge University Press, 431-458.

Allison G (2019 [2017]) Destined for War. Can America and China Escape Thucydides's Trap? Melbourne/London: Scribe.

Antonelli C (2011) The economic complexity of technological change: Knowledge interaction and path dependence. In: Antonelli C (ed.) Handbook on the Economic Complexity of Technological Change. Cheltenham, UK/Northampton, MA: Edward Elgar, 3-62.

Antonelli C (2015) Innovation as creative response: A reappraisal of Schumpeterian legacy. History of Economic Ideas 23(2): 99-118.

Appelbaum RP, Parker R, Cao C and Gereffi G (2011) China's (not so hidden) developmental state. Becoming a leading nanotechnology innovator in the twenty-first century. In: Block F and Keller MR (eds) State of Innovation. The US Government's Role in Technology Development. New York: Routledge, 217-235.

Arthur WB (2009) The Nature of Technology. What It Is and How It Evolves. New York/ London/Toronto/Sydney: Free Press.

Audretsch DB and Feldman MP (1996) Innovative clusters and the industry life cycle. Review of Industrial Organization 11: 253-273.

Bartunek JM and Necochea RA (2000) Old insights and new times: Kairos, Inca cosmology, and their contributions to contemporary management inquiry. Journal of Management Inquiry (9)2: 103-113.

Basalla G (2009 [1988]) The Evolution of Technology. Cambridge: Cambridge University Press.

Bathelt H and Glückler J (2018 [2002]) Wirtschaftsgeographie [Economic Geography]. Stuttgart: Eugen Ulmer.

Bauer R (2006) Gescheiterte Innovationen. Fehlschläge und technologischer Wandel [Failed Innovations. Failures and Technological Change]. Frankfurt/New York: Campus.

Beck H (2014) Behavioural Economics. Eine Einführung. Wiesbaden: Springer Gabler. Benjamin W (2007) Kairos. Schriften zur Philosophie. Ausgewählt und mit einem Nachwort von Ralf Konersmann [Kairos. Writings on Philosophy. Selected and with a Postscript by Ralf Konersmann]. Frankfurt am Main: Suhrkamp. 
Bergman EM (2007) Cluster life-cycles: An emerging synthesis. In: Karlsson C (ed.) Handbook of Research on Cluster Theory. Cheltenham, UK/Northampton, MA: Edward Elgar, 114-132.

Block F (2011) Innovation and the invisible hand of government. In: Block F and Keller MR (eds) State of Innovation. The US Government's Role in Technology Development. New York: Routledge, 1-26.

Block F and Keller MR (eds) (2011) State of Innovation. The US Government's Role in Technology Development. New York: Routledge.

вмв F (2004a) BioRegionen in Deutschland. Starke Impulse für die nationale Technologieentwicklung. Berlin: BMBF (FMER).

вмв F (2004b) Bundesbericht Forschung. Berlin: BмBF (FMER).

вмв F (2007) Deutschlands Spitzencluster. Mehr Innovation. Mehr Wachstum. Mehr Beschäftigung. Berlin: вмвғ.

Borrás S and Edquist C (2019) Holistic Innovation Policy. Theoretical Foundations, Policy Problems, and Instrument Choices. Oxford: Oxford University Press.

Boschma R (1996a) New industries and windows of locational opportunity. A longterm analysis of Belgium. Erdkunde - Archive of Scientific Geography 51: 12-22.

Boschma R (1996b) The window of locational opportunity-concept. Quaderni Working Paper DSE 26o. Alma Mater Studiorum - Università di Bologna, Dipartimento di Scienze Economiche (DSE), Bologna. Dor: http://dx.doi.org/ 10.6o92/unibo/amsacta/505o.

Boschma R (1999) The rise of clusters of innovative industries in Belgium during the industrial epoch. Research Policy 28: 853-871.

Boschma RA and van der Knaap GA (1999) New high-tech industries and windows of locational opportunity: The role of labour markets and knowledge institutions during the industrial era. Geografiska Annaler $81 \mathrm{~B}(2)$ : 73-89.

Boutin JDK (2013) American Technology Policy. Evolving Strategic Interests after the Cold War. Washington, DC: Potomac Books.

Brenner T and Schlump C (2011) Policy measures and their effects in the different phases of the cluster life cycle. Regional Studies 45(10): 1363-1386.

Bush V (196o [1945]) Science - The endless frontier. A report to the President on a program for postwar scientific research. July 1945. Reprinted July 1960. Washington, DC: National Science Foundation.

Cai Y and Etzkowitz H (2020) Theorizing the Triple Helix model: Past, present, and future. Triple Helix 6(1): 1-38. Dor: https://10.1163/21971927-bja1oooo3.

Cai Y, Pugh R and Liu C (2017) A framework for analysing the role of innovation policy in regional innovation system development. International Journal of Innovation and Regional Development (7)4: 237-256.

Canzler W, Wentland A and Simon D (2011) Wie entstehen neue Innovationsfelder? Vergleich der Formierungs- und Formungsprozesse in der Biotechnologie und Elektromobilität. Discussion Paper SP III 2011-6o1. Berlin: WZB. 
Carroll GR and Hannan MT (2000) The Demography of Corporations and Industries. Princetion, NJ: Princeton University Press.

Chandler Jr., A.D. (2005). Inventing the Electronic Century. The Epic Story of the Consumer Electronics and Computer Industries. Cambridge, MA, London, England: Harvard University Press.

Clark C (2013) Die Schlafwandler. Wie Europa in den Ersten Weltkrieg zog. [The Sleepwalkers. How Europe Went To War in 1914]. München: Deutsche Verlags-Anstalt.

Cockburn IM and Stern S (2010) Finding the endless frontier: Lessons from the life sciences innovation system for technology policy. Capitalism and Society 5(1): Art. 4. DOI: 10.2202/1932-0213.1069.

Dalum B Pedersen CÖR and Villumsen G (2005) Technological life-cycles: Lessons from a cluster facing disruption. European Urban and Regional Studies (12):229-246.

David P (2006 [2005]) Path dependence in economic processes: Implications for policy analysis in dynamical systems contexts. In: Doper K (ed.) The Evolutionary Foundations of Economics. Cambridge: Cambridge University Press, 151-194.

Demandt A (2015) Zeit. Eine Kulturgeschichte [Time. A Cultural History]. Berlin: Propyläen, Ullstein-Buchverlage.

Defoe D (2006 [1697]) Ein Essay über Projekte, London 1697. Herausgegeben und kommentiert von Christian Reder. Vienna/New York: Edition Transfer/Springer.

Dohse D (2000) Technology policy and the regions - The case of the BioRegio contest. Research Policy 29(9): 1111-1133.

Dohse D (2007) Cluster-based technology policy - The German experience. Industry and Innovation 14(1): 69-94.

Dohse D and Staehler T (2008) BioRegio, BioProfile and the rise of the German biotech industry. Kiel Working Paper 1456. Kiel: IfW.

Doper K (2016) Evolutionary economics: A theoretical framework. In: Doper K (ed.) The Evolutionary Foundations of Economics. Cambridge: Cambridge University Press, 3-55.

Drucker PF (1993 [1985]) Innovation and Entrepreneurship. Practice and Principles. New York/London/Toronto/Sydney: Harper.

Duranton G (2011) California dreamin': The feeble case for cluster policies. Review of Economic Analysis 3: 3-45.

Edler J and Fagerberg J (2017) Innovation policy: What, why, and how. Oxford Review of Economic Policy 33(1): 2-23.

Etzkowitz H (2012) An innovation strategy to end the second great depression. European Planning Studies 2O(9): 1439-1453. Dor: 10.108o/og65433.2012.709o6o.

Etzkowitz H and Leydesdorff L (2000) The dynamics of innovation: From national systems and "mode 2 " to a Triple Helix of university - industry - government relations. Research Policy 29: 109-123.

Etzkowitz H and Zhou C (2018 [2008]) The Triple Helix. University - IndustryGovernment Innovation and Entrepreneurship. London and New York: Routledge. 
Fornahl D, Hassink R, Klearding C, Mossig I and Schröder H (2012) From the old path of shipbuilding onto the new path of offshore wind energy? The case of Northern Germany. European Planning Studies 20(5).

Fornahl D, Henn S, Menzel M-P (2010) Emerging Clusters. Theoretical, Empirical and Political Perspectives on the Initial Stage of Cluster Evolution. Cheltenham, UK and Northampton, MA: Edward Elgar.

Fornahl D, Heimer T, Campen A, Talmon-Gros L and Treperman J with the cooperation of Gerken P, Knop S, Reinecke I and Schrapers M (2015) Cluster als Paradigma der Innovationspolitik - Eine erfolgreiche Anwendung von Theorie und Praxis? Studien zum deutschen Innovationssystem 13-2015. Bremen, Frankfurt am Main: CRIE Centre for Regional and Innovation Economics, Universität Bremen, Technopolis Deutschland GmbH.

Frommhold-Eisebith M (2014). Erfolgsgeschichte oder Modeerscheinung? Clusterpolitik im Spannungsfeld von Theorie und Praxis. In: Beck RC, Heinze RG and Schmid J (eds) Zukunft der Wirtschaftsförderung. Wiesbaden: Nomos, 67-88.

Giachetti C and Marchi G (2017) Successive changes in leadership in the worldwide mobile phone industry: The role of windows of opportunity and firms' competitive action. Research Policy 46(2): 352-364.

Giesecke S (2000) The contrasting roles of government in the development of biotechnology industry in the US and Germany. Research Policy 29: 205-223.

Giesecke S (2001) Von der Forschung zum Markt: Innovationsstrategien und Forschungspolitik in der Biotechnologie. Berlin: Edition sigma.

Gigerenzer G (2014) Risiko. Wie man die richtigen Entscheidungen trifft [Risk Savvy. How to Make Good Decisions]. Munich: Random House.

Godin B (2017) Models of Innovation. The History of an Idea. Cambridge, MA, London, England: The MIT Press.

Hamel G and Prahalad CK (2010) Strategic intent. Harvard Business Review Classics. Boston, MA: Harvard Business Review Press.

Hammer M and Champy J (1995 [1993]) Business Reengineering. Die Radikalkur für das Unternehmen [Reengineering the Corporation]. Frankfurt and New York: Campus.

Hospers G-J, Sautet F and Desrochers P (2008) Silicon somewhere: is there a need for cluster policy? In: Karlsson C (ed.) Handbook of Research on Innovation and Clusters. Cases and Policies. Cheltenham: Edward Elgar, 430-446.

Johnson B (2010) Toward a New Approach to National Systems of Innovation. In: Lundvall, B.-Â (ed.). National Systems of Innovation. Toward a Theory of Innovation and Interactive Learning. London, New York and Delhi: Anthem Press, 21-45

Jullien F (2006) Vortrag vor Managern über Wirksamkeit und Effizienz in China und im Westen, [Lecture to Managers on Effectiveness and Efficiency in China and the West], Internationaler Merve Diskurs 289. Berlin: Merve Verlag. 
Jullien F (2008) Umweg über China: In: Kontroverse über China. Sino-Philosophie [Detour via China. In: Controversy on China]. Berlin: Merve Verlag, 7-329.

Kahneman, D. (2012 [2011]) Thinking, Fast and Slow. London: Penguin.

Kang $\mathrm{H}$ and Song J (2017) Innovation and recurring shifts in industrial leadership: Three phases of change and persistence in the camera industry. Research Policy 46(2): $376-387$.

Kasper W et al. (eds) (2009) Kairos. In: Lexikon für Theologie und Kirche. Fünfter Band. [Dictionary for Theology and Church. 5th Vol.] Sonderausgabe. Freiburg, Basel, Wien Herder, 1129-1131.

Kay J and King M (2020) Radical Uncertainty. Decision-making for an unknowable future. London: The Bridge Street Press.

Keese C (2014) Silicon Valley. Was aus dem mächtigsten Tal der Welt auf uns zukommt, [Silicon Valley. What Challenges Face Us from the most Powerful Valley of the World], München: Knaus.

Kittel G (ed.) (1965) Theological Dictionary of the New Testament [Theologisches Wörterbuch zum Neuen Testament]. Grand Rapids, MI: Eerdmans.

Kiechel III W (2010) The Lords of Strategy. The Secret Intellectual History of the New Corporate World. Boston, MA: Harvard Business Review Press.

Kiese M (2012). Regionale Clusterpolitik in Deutschland. Bestandsaufnahme und interregionaler Vergleich im Spannungsfeld von Theorie und Praxis. Marburg: Metropolis.

Kiese M (2014). Regionale Clusterpolitik in Deutschland: Bestandsaufnahme und interregionaler Vergleich. In: Beck, R.C., R.G. Heinze and J. Schmid (eds.) (2014), Zukunft der Wirtschaftsförderung. Wirtschafts- und Sozialpolitik 14. Wiesbaden: Nomos, 169-194.

Kiese M (2017). Regional cluster policies in Germany: challenges, impacts and evaluation practices. Journal of Technology Transfer. DOI 10.1007/s10961-017-9589-5.

Knight FH (1921). Risk, Uncertainty and Profit. Boston and New York: Houghton Mifflin Company.

Konersmann R (2007) Nachwort. Walter Benjamins philosophische Kairologie. In: Benjamin, W (2007) Kairos. Schriften zur Philosophie. Frankfurt am Main:Suhrkamp, 327-348.

Krajewski M (2008 [2004]) Über Projektemacherei. Eine Einleitung [On Project Making. An Introduction]. In: Krajewski M (ed.) Projektemacher. Zur Produktion von Wissen in der Vorform des Scheiterns [Project Makers. On the Production of Knowledge in the Preform of Failure]. Berlin: Kulturverlag Kadmos, 7-25.

Kuhn T (2012 [1962]) The Structure of Scientific Revolutions. 5oth anniversary edition with an introductory essay by Ian Hacking. Chicago, London: The University of Chicago Press. 
Lawton Smith H and Leydesdorff L (2014) The Triple Helix in the context of global changes: dynamics and challenges. Prometheus 32(4). DoI: 10.1080/08109028.2014 .9721.

Lee $\mathrm{K}$ and Malerba F (2017) Catch-up cycles and changes in industrial leadership: Windows of opportunity and responses of firms and countries in the evolution of sectoral systems. Research Policy 46(2): 338-351.

Leydesdorff L (2000) The Triple Helix: An evolutionary model of innovations. Research Policy 29: 243-255.

Leydesdorff L (2012) The Triple Helix, quadruple helix, ..., and n-tuple of helices: Explanatory models for analyzing the knowledge-based economy? Journal of the Knowledge Economy 3: 25-35. DOI 10.2007/s13132-011-0049-4.

Lundvall, B-ÂA (ed.) (2010) Introduction. In: Lundvall B-Â (ed.) National Systems of Innovation. Toward a Theory of Innovation and Interactive Learning. London, New York and Delhi: Anthem Press, 1-19.

Martin R (2010) Rethinking Regional Path Dependence: Beyond Lock-in to Evolution. The 2009 Roepke Lecture in Economic Geography. Economic Geography (3)1: 1-27.

Martin R and Sunley P (2011) Conceptualizing cluster evolution: Beyond the life cycle model? Regional Studies 45(10): 1299-1318.

Mazzucato M (2014) The Entrepreneurial State. Debunking Public vs. Private Sector Myths. London, New York and Delhi: Anthem Press.

McMillan GS, Narin F and Deeds DL (200o) An analysis of the critical role of public science in innovation: The case of biotechnology. Research Policy 29: 1-8.

Merton RK and Barber E (2006 [2004]). The Travels and Adventures of Serendipity. Princeton and Oxford: Princeton University Press.

Miller CR and Selzer J (1985) Special topics of argument in engineering reports. In: Odell L and Goswami D (eds) Writing in Non-Academic Settings. New York: Guilford, 309-341.

Miller CR (1992) Kairos in the rhetoric of science. In: Witte SP, Nakadate N and Cherry RD (eds) A Rhetoric of Doing. Essays on Written Discourse in Honor of James L. Kinneavy. Carbondale and Edwardsville: Southern Illinois University Press, 310-327.

Mintzberg H (1995 [1994]) Die Strategische Planung. Aufstieg, Niedergang, Neubestimmung. [The Rise and Fall of Strategic Planning]. Munich/Vienna/London: Hanser/ Prentice-hall International.

Mokyr J (1992 [1990]) The Lever of Riches. Technological Creativity and Economic Progress. Oxford: Oxford University Press.

Moore, J.F. (1997) [1996]). The Death of Competition. Leadership \& Strategy in the Age of Business Ecosystems. New York: Harper Business, HarperCollins Publishers.

National Science and Technology Council (2000) National Nanotechnology Initiative. The Initiative and its Implementation Plan. Washington, DC: National Science and 
Technology Council, Committee on Technology, Subcommittee on Nanoscale, Engineering and Technology.

Nelson RR and Winter SG (1996 [1982]) An Evolutionary Theory of Economic Change. Cambridge, MA and London: The Belknap Press of Harvard University Press.

Newfield C (2011) Avoiding network failure. The case of the national nanotechnology initiative. In: Block F and Keller MR (eds) State of Innovation. The US Government's Role in Technology Development. New York: Routledge, 282-299.

Peters T and Waterman Jr RH (2015 [1982]) In Search of Excellence. Lessons from America's Best-Run Companies. London: Profile Books Ltd.

Porter ME (1986 [1985]) Wettbewerbsvorteile. Spitzenleistungen erreichen und behaupten. [Competitive Advantage]. Frankfurt: Campus.

Porter ME (1992 [1980]). Wettbewerbsstrategie. [Competitive Strategy]. Frankfurt: Campus-Verlag.

Porter ME (1998a) On Competition. Boston, MA: Harvard Business School Publishing.

Porter ME (1998b) Clusters and the new economics of competition. Harvard Business Review (Nov/Dec): 77-9o.

Porter ME (1999 [1991]) Nationale Wettbewerbsvorteile. Erfolgreich konkurrieren auf dem Weltmark [The Competitive Advantage of Nations]. Management-Bibliothek. Vienna: Wirtschaftsverlag Ueberreuter.

Radkau J (2008) Technik in Deutschland. Vom 18. Jahrhundert bis heute [Technology in Germany. From the 18th Century to the Present]. Frankfurt/New York: Campus.

Ranga MH and Etzkowitz H (2013) Triple Helix systems: An analytical framework for innovation policy and practice in the Knowledge Society. Industry \& Higher Education 27(3): 237-262. Dor: https://10.5367/ihe.2013.0165.

Reder C (2006) Daniel Defoe. Beginn des Projektzeitalters [Beginnings of the Projecting Age]. In: Defoe D (2006 [1697]) Ein Essay über Projekte. London 1697. Herausgegeben und kommentiert von Christian Reder [An Essay on Projects, London 1697, edited and commented by Christian Reder]. Vienna/New York: Edition Transfer/Springer.

Rheinberger H-J (2018) Experimentalität, Hans-Jörg Rheinberger im Gespräch über Labor, Atelier und Archiv [Experimentality. Hans Jürgen Rheinberger in a Conversation on Laboratory, Studio and Archive]. Berlin. Kulturverlag Kadmos.

Rothgang M and Lageman B (2017) Windows of opportunity in innovation policy: Germany's leading-edge cluster programme as "experiment". Paper presented at DRUID17, NYU Stern School of Business, New York, June 12-14. Druid Society. Available at: https://conference.druid.dk/acc_papers/lkliggd15igrq7ra4ol174398jy9 .pdf (accessed 31 July 2020).

Rothgang M, Dehio J and Lageman B (2017) Analysing the effects of cluster policy: What can we learn from the German leading-edge cluster competition? The Journal of Technology Transfer. DoI: 10.1007/s1og61-017-9616-6. 
Rothgang M, Dehio J and Lageman B (2019) Analysing the effects of cluster Policy: What can we learn from the German leading-edge cluster competition? The Journal of Technology Transfer 44: 1673-1697. DoI: https://10.1007/s10961-o17-9616-6.

Sandkühler HJ (2009) Kritik der Repräsentation. Einführung in die Theorie der Überzeugungen, der Wissenskulturen und des Wissens. Frankfut am Main: Suhrkamp.

Saxenian AL (1996 [1994]) Regional Advantage. Culture and Competition in Silicon Valley and Route 128. Cambridge, MA and London: Harvard University Press.

Saxenian AL (2006) The New Argonauts. Regional Advantage in a Global Economy. Cambridge, MA and London: Harvard University Press.

Schot $\mathrm{J}$ and Steinmueller WE (2018) Three frames for innovation policy. R\&D, systems of innovation and transformative change. Research Policy 47: 1554-1567.

Schumer J (2009) Nanotechnologie. Spiele mit Grenzen. [Nanotechnology. Playing with Boundaries]. Franfurt am Main: Suhrkamp.

Schumpeter JA (1947). The Creative Response in Economic History. The Journal of Economic History 7(2): 149-159.

Schumpeter JA (1975 [1942]) Kapitalismus, Sozialismus und Demokratie. [Capitalism, Socialism andDemocracy.] transl. by S. Preiswerk, 4. Aufl., München:A. FrankeVerlag. Schumpeter JA (2006 [1912]) Theorie der wirtschaftlichen Entwicklung [Theory of Economic Development]. Berlin: Duncker \& Humblot.

Shiller RJ (2019) Narrative Economics. How Stories Go Viral and Drive Major Economic Events. Princeton and Oxford: Princeton University Press.

Shin J-S (2017) Dynamic catch-up strategy, capability expansion and changing windows of opportunity in the memory industry. Research Policy 46(2): 404-416.

Tversky A and Kahneman D (2020 [1982])Judgement under uncertainty. In: Kahneman D, Slovic P and Tversky A (eds) Judgement under Uncertainty: Heuristics and Biases. Cambridge: Cambridge University Press, 3-20.

Tyre MJ and Orlowski WJ (1994) Windows of opportunity: Temporal patterns of technological adaptation in organizations. Organization Science 5(1): 1-118. DoI: https:// doi/10.1287.orsc.5.1.98

Uyarra E and Ramlogan R (2016) The impact of cluster policy on innovation. In: Edler J, Cunningham P, Gök A and Shapira P (eds.) Handbook of Innovation Policy Impact. London: Edward Elgar, 196-231.

Vicente J (2016) Économie des clusters. Paris: Éditions la Découverte.

Vincenti WG (1993 [1990]) What Engineers Know and How They Know It. Analytical Studies from Aeronautical History. Johns Hopkins Studies in the History of Technology. Baltimore and London: Johns Hopkins University Press.

Westhead P and Wright M (2013) Entrepreneurship. A Very Short Introduction. Oxford: Oxford University Press.

Wieland T (2011) Neue Politik auf alten Pfaden. Biotechnologieförderung in der Bundesrepublik Deutschland. In: Kehrt C, Schüssler P, Weitze M-D (eds) Neue 
Technologien in der Gesellschaft. Akteure, Erwartungen, Kontroversen und Konjunkturen. Bielefeld: transcript, 249-277.

Wolf T, Cantner U, Graf $\mathrm{H}$ and Rothgang M (2019) Cluster ambidexterity towards exploration and exploitation: Strategies and cluster management. The Journal of Technology Transfer 44: 1840-1866. DoI: https://doi.org/10.1007/s10961-017-9617-5

Zimmermann W (2014 [2012]). Unternehmer sind Verrückte. Wie Unternehmer Grenzen überwinden und was Manager von ihnen lernen können. 2., aktual. Auflage. Wiesbaden: Springer Gabler. 